\title{
Motivating Information Technology Professionals: The case of New Zealand
}

\author{
Shoaib Ahmed \\ Eagle Technology \\ shoaib_ahmed@eagle.co.nz
}

\author{
Nazim Taskin \\ Massey University
}

\section{David Pauleen}

Massey University

\section{Jane Parker}

Massey University

\section{Abstract}

IT professionals play a critical role in organizations. Research indicates that they may be unique in their attitudes toward motivation and job satisfaction. In New Zealand, a shortage of skilled professionals may contribute to or impact on motivation. Using a modified model of Herzberg's two-factor theory by Smerek and Peterson (2007), this research seeks to answer the question: what motivates New Zealand IT professionals? In response, an online questionnaire was distributed to a population of New Zealand IT professionals and the data analysed using Partial Least Squares to understand the relationship between the various dimensions of job satisfaction, the impact of personal and job characteristics, and turnover intention. The findings show that the New Zealand IT professional is primarily motivated by the nature of his or her work, followed by perceptions of responsibility, and how supervisors encourage an environment for such. Satisfaction with salary is a predictor to a lesser degree. Perhaps somewhat surprisingly, professional growth opportunities, career advancement, and recognition do not have a statistically-significant positive association with motivation. We conclude that, to motivate their IT workforce, organizations should: 1) focus on the nature of the jobs that IT professionals undertake; 2) train supervisors to provide an empowering environment; 3) offer competitive salaries to retain top talent; 4) not hesitate to employ IT professionals born outside New Zealand; and 5) take account of the singularities of the New Zealand labour market in seeking to attract, recruit and retain IT professionals. Implications for policy, practice and theory are discussed.

Keywords: IT Professionals; Motivation; Career Advancement; Job Satisfaction; Turnover

\section{Introduction}

Managers are interested in understanding motivation to deliver better employee performance outcomes. Psychologists have been interested in job satisfaction and motivation since the 1930s (Locke \& Latham, 2002) and researchers have investigated the effects of supervision (Roethlisberger \& Dickson, 1939), human cognitive growth needs (Alderfer, 1969; Herzberg, 2003; Maslow, 1943; McClelland \& Burnham, 1995) and psychological processes (Adams, 1965; Bandura, 1977; Locke, 1977; Vroom, 1964).

While key schools of thought were formed decades ago, the subject remains relevant. Amazon offers nearly 10,000 books on motivation. A typical New Zealand (NZ) University Library contains over 200,000 academic journal articles on this topic. This mass of literature can hinder the choice of appropriate, context-sensitive recommendations for NZ IT managers.

A complicating factor is that IT professionals might somehow be distinct from others in their attitudes to motivation (Ferratt \& Short, 1986), making motivation theories based on general populations less applicable. Otherwise, managers may be susceptible to implementing 
recommendations that conform to prevalent management attitudes rather than those tailored to the motivations of IT professionals.

Declining levels of job satisfaction levels in NZ firms are anecdotally suggested but raise concerns about potential negative impacts on staff motivation and performance. This concern is valid given previous research on motivation and performance (e.g. Judge, Thoresen, Bono, \& Patton, 1998; McMurtrey, Grover, Teng, \& Lightner, 2002). A NZ Ministry of Business Innovation and Employment (MBIE) (2015) report acknowledged shortages in the skilled ICT sector staff, which has consequences for workload, quality of life and stress. Moore (2000) indicated that these features contribute to dissatisfaction among IT professionals, causing them to look for alternative opportunities. This is couched within the wider trend in Western nations of a loss of leisure time (Schor, 2008).

Despite the sizeable and diverse literature on motivation, no one theory has gained universal acceptance. Debate on work motivation is ongoing (Locke \& Latham, 2004), as is that over whether IT professionals share the same motivational characteristics. Extant literature indicates that IT professionals' motivational drivers are somewhat unique. Williamson (1996) identifies 'expressively oriented' workers, who may be influenced by factors other than pay, contrasting with most organizational literature which assumes workers are instrumentally oriented (Smith \& Shields, 2013). Little literature exists in this area in NZ, and what does focuses on medicine (e.g. Kluger \& Bryant, 2008).

Major studies on motivation have traditionally focused on non-IT industries (Ghazzawi, 2008), including in NZ (e.g. Boxall, Macky, \& Rasmussen, 2003). Previous analyses of NZ technology firms have indicated indigenous approaches to compensate for geographical isolation and size (Souder, Buisson, \& Garrett, 2001). Some work has viewed NZ as a unique environment due to a relative lack of innovative human resources (HR) practices (e.g. Guthrie, 2001) and more recent work still echoes the importance of organizational scale for HR development. The tech sector is a large contributor to NZ's economy, with over 28,000 companies employing almost $5 \%$ of workers, but calls to develop a sustainable local talent base have focused more on the education system (e.g. NZ Technology Industry Association (NZTech), 2016) than workplace HR strategy. A lag persists between progress in HR approaches in NZ workplaces and other developed economies due to a number of local features: small NZ workplaces not having a full in-house HR function (Ryan, 2012; Parker, 2013) and limited HR outsourcing; HR not widely on par with other management functions (e.g. Arrowsmith \& Parker, 2012); and a local cultural identity of 'self-sufficiency' (e.g. Toulson \& Foster, 2013),

Locke and Latham's (2004) call for investigating general and situation-specific contributors requires the exploration of a theory that can accommodate both. This study assists in greater understanding of such in the NZ context. To better understand IT professionals' motivational issues in NZ, we address the question: what motivates the NZ IT professional? The results should be of conceptual and practical interest to IT managers, firms employing IT professionals, policy-makers intent on maximizing NZ's capability in this sector, academics, and IT professionals.

Our review of relevant literature is followed by a description of the research methods used in this study, its findings, and finally, key conclusions and recommendations.

\section{Literature Review}

Academic interest in motivation began with the famous Hawthorne experiments (Roethlisberger \& Dickson, 1939) which found that the performance of professionals improved due to their knowledge of being observed, regardless of modifications to working conditions (e.g. changes to schedules, meal breaks, etc.). The study was criticised (Sykes, 1965; Wickström \& Bendix, 2000) but the Hawthorne Experiments led to a series of theories focusing on the cognitive growth needs of humans as a source of motivation. 


\subsection{Cognitive Needs-Based Theories}

The most famous of cognitive needs theories is Maslow's (1943) hierarchy of needs: physiological, safety, love, esteem, and self-actualisation. As lower needs are satisfied, higher order needs appear. Humans are motivated by the desire to attain or perpetuate the conditions that satisfy these needs. While actions can be driven by multiple needs, the more potent need is the primary motivator. Maslow's work has informed many fields, including psychology, management and education. The needs hierarchy has been challenged for various reasons (Wahba \& Bridwell, 1976; Haire, Ghiselli, \& Porter, 1966), and Alderfer (1969) sought to reframe Maslow's work beyond these criticisms through his existence, relatedness and growth (ERG) theory, which presents the same needs without a hierarchy. McClelland (1961) proposed an alternative to Maslow by identifying achievement, affiliation and power as motivators of human behaviour. He asserted that these three needs are acquired over time through experiences and can be taught (McClelland, 1965).

Herzberg first linked job satisfaction and motivation in his Two-Factor Theory (Herzberg, Mausner, \& Snyderman, 1959). Most of his subjects reported happiness with jobs when they were successful and saw potential for growth, leading him to term these motivating factors. In contrast, when these subjects were asked about unhappiness, they most commonly responded about conditions surrounding the job (hygiene factors). Herzberg argued that sources of job satisfaction and dissatisfaction are different; addressing causes of job dissatisfaction lessens job dissatisfaction, rather than provides job satisfaction. He thus championed enriching the job itself to increase motivation.

Herzberg's work faced criticism primarily related to his method of research (e.g., Hardin, 1965; Gordon, Pryor, \& Harris, 1974). However, several studies replicated Herzberg's findings (Myers, 1964; Saleh, 1964). Herzberg (1968) later substantiated his earlier conclusions with studies from Italy, Israel, Japan, India, Zambia and South Africa. He also distinguished between motivation, an internal engine, and movement, where actions are due to motivation of a third party. Lindsay, Marks, and Gorlow (1967) concluded that the theory has been both demonstrated and challenged in part.

Vroom was instrumental in adopting psychological processes as a key determinant of motivation through his work in developing Expectancy Theory, representing a move away from the prevailing needs-based thinking (Locke \& Latham, 2004). His theory identified three psychological processes determining motivation: valence (the desire for attaining or avoiding an outcome); instrumentality (belief in how strongly an action is likely to lead to a desired outcome); and expectancy (belief in whether the desired outcome is feasible (Vroom, 1964)).

However, Vroom did not discuss the origins of valence, instrumentality or expectancy. Developing a theoretical model and testing it on a group of managers, Porter and Lawler (1968) identified motivation for effort as dependent on an individual's perceived value of an outcome and his or her perception as to whether effort will lead to success. They noted that effort does not equate to performance, which is further dependent on the ability of the individual and role clarity. They further argued that the link between performance and satisfaction is tenuous and depends on rewards - intrinsic more than extrinsic - and their perception of equity relative to the outcome achieved (Schuster, Clark, \& Rogers, 1971).

Bandura (1977) took the role of expectancy further with his theory of self-efficacy. While efficacy itself cannot be considered the motivator, it affects motivation through its impact on an individual's goals and aspirations. This is what sustains effort through adversity. Individuals are only motivated to pursue a course of action they believe is within their capability, and routinely exclude options which they believe are beyond their means (Bandura, 2000). However, his work is criticised for not controlling for the effects of behaviour approach tests in a social context (Tryon, 1981). Table 1 summarises the major theories and their proponents. 


\begin{tabular}{|c|c|c|c|}
\hline Basis & Theory & Researcher & Primary idea \\
\hline \multirow{4}{*}{ 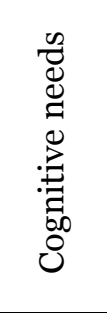 } & $\begin{array}{l}\text { Hierarchy of } \\
\text { needs }\end{array}$ & (Maslow, 1943) & Humans have five basic needs in order of priority. \\
\hline & ERG theory & ) & Iaslow's \\
\hline & $\begin{array}{l}\text { Acquired } \\
\text { needs theory }\end{array}$ & $\begin{array}{l}\text { (McClelland, } \\
\text { 1961) }\end{array}$ & $\begin{array}{l}\text { Needs are acquired through experience and can be } \\
\text { taught. }\end{array}$ \\
\hline & $\begin{array}{l}\text { Two- } \\
\text { theor }\end{array}$ & (Herzberg e & $\begin{array}{l}\text { Satisfaction and dissatisfaction are separate scales. } \\
\text { What dissatisfies, if addressed, only reduces } \\
\text { dissatisfaction. It does not satisfy. }\end{array}$ \\
\hline \multirow{4}{*}{ 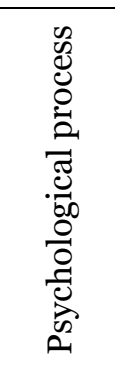 } & $\begin{array}{l}\text { Expectancy } \\
\text { theory }\end{array}$ & (Vroo & $\begin{array}{l}\text { Motivation is dependent on an individual's perceived } \\
\text { value of an outcome and his or her conviction on } \\
\text { whether effort will lead to success. }\end{array}$ \\
\hline & & $\begin{array}{l}\text { (Porter } \\
\text { Lawler, }\end{array}$ & for the expectancy theory. \\
\hline & $\begin{array}{l}\text { Theory of } \\
\text { self-efficacy }\end{array}$ & (Bandura, 1977) & $\begin{array}{l}\text { Efficacy determines an individual's goals and } \\
\text { aspirations. }\end{array}$ \\
\hline & $\begin{array}{l}\text { Goal-setting } \\
\text { theory }\end{array}$ & $\begin{array}{l}\text { (Locke \& } \\
\text { Latham, 2002) }\end{array}$ & $\begin{array}{l}\text { Faced with extreme goals, individuals are motivated to } \\
\text { find new ways to achieve them. }\end{array}$ \\
\hline
\end{tabular}

Table 1: Major theories on motivation

\subsection{Motivation in an IT Context}

Research on motivation and job satisfaction in the IT field is not new. Goldstein and Rockart (1984) investigated the motivation of software developers and analysts in the eighties. The prevailing motivation approaches consider rewards and recognition (Beecham, Baddoo, Hall, Robinson, \& Sharp, 2008). Several experts have claimed that IT professionals derive motivation from what they do, and technical challenges that they can overcome (Ramachndran \& Rao, 2006; Tanner, 2003). Further support for differences in personalities between IT and non-IT professionals is found in Wynekoop and Walz (1998). Expectation of market conditions compared to one's present circumstances can play a role in job satisfaction (Jiang \& Klein, 2002). This is strengthened by studies finding that access to the latest technology and training contributes to higher levels of satisfaction than remuneration (Jyothi \& Ravindran, 2012; Shuck, Twyford, Reio, \& Shuck, 2014).

Anjali and Anand (2015) note specific characteristics of IT professionals, such as their choice of employment due to high skill levels, unpredictable work schedules in the face of project deadlines, pressures of meeting service levels, often being based remotely, and sitting for long periods. They note that these lead to reduced efficiency and productivity as a result of boredom unless tasks can be kept exciting. Rajagopal and Abraham (2009) find that time pressure contributes to a different hierarchy of needs. IT professionals show distinctly lower social and psychological needs. Their needs progress from safety to self-esteem, with the authors concluding that higher-order needs are more relevant for them.

Wynekoop and Walz (1998) found that those entering IT professions were more creative than others. However, Schambach and Blanton (2002) found a dichotomy. Organizations acknowledge the need for skilled IT professionals and aggressively pursue them with attractive remunerations and stock options. Yet many fail to create an environment where these skilled employees, especially those in mid-career, can maintain skills to produce necessary innovation. Consequently, concern over continued employability plays a key role in reducing motivation.

Other researchers contest the proposition that IT professionals are different in their attitude to motivation. Ferratt and Short (1986) asserted that studies claiming differences have not used similar occupational groups (i.e., IT and non-IT staff in the same company), causing misinterpretation (see also Im and Hartman (1990) and Smith and Speight (2006)).

This study's goal is to examine a) the motivation of IT professionals b) in the NZ context, which is considered to be unique on account of the nature and scale of its HR practices (Guthrie, 
2001; Toulson \& Foster, 2013). Drawing on Herzberg's well-known two-factor theory, this focus aligns with the call from Locke and Latham (2004) to investigate situation-specific contributors to theory.

\subsection{Two-Factor Theory}

The two-factor theory was originally derived from the job attitudes of 203 accountants and engineers in Pittsburgh. Participants were asked to recall times when and why they were more satisfied and dissatisfied than usual (Herzberg et al., 1959). The theory was refined over 12 further investigations. Contrary to previous assumptions, job satisfaction (motivation) and dissatisfaction (hygiene) had distinctive contributions. Herzberg related hygiene factors to the need to avoid pain. These include company policy and administration, supervision, relationship with supervisor, work conditions, relationships with peers and subordinates, salary, personal life, status, and security. In contrast, he compared the motivation factors to the unique human ability to succeed through achievement and resulting psychological growth (Herzberg, 1968). Motivation factors include recognition, the work itself, achievement, growth, responsibility and advancement. Herzberg's findings indicate that motivation factors have a four-fold impact on job satisfaction when compared with hygiene factors. The best summary of the two-factor theory is provided by Herzberg et al. (1959: 114) where the authors declare: "(t)he factors that lead to positive job attitudes do so because they satisfy the individual's need for self-actualization." Based on this theory, this study proposes the following hypotheses:

H1: Intrinsic motivation factors (motivators) are positively associated with job satisfaction for IT professionals in NZ; and

H2: Extrinsic motivation factors (hygiene factors) are positively associated with job satisfaction for IT professionals in NZ.

\subsection{Motivation and Personal Characteristics}

Personal characteristics are cited as contributing to or moderating motivation among workers. These include age (Allen \& Meyer, 1993), gender (Deci, Koestner, \& Ryan, 1999; Magee, 2013) and even local community attitudes (Shiu, Hassan, \& Parry, 2015). The effect of education on job satisfaction appears less certain. Some researchers contend that those with higher levels of education are likely to be less satisfied due to the routine nature of work tasks (Bruce, Bonjean, \& Williams Jr., 1968; Carrell \& Elbert, 1974). However, others argue that the higher extrinsic rewards achieved through higher education are likely to have the opposite effect (Glenn, Taylor, \& Weaver, 1977; Lee \& Wilbur, 1985). Accordingly, this study proposes that:

H3: Personal characteristics have a positive association with job satisfaction for IT professionals in NZ.

\subsection{Motivation and Job Characteristics}

Academics have identified job characteristics as a key contributor to perceptions of job satisfaction and turnover intention (Kristof-Brown, Zimmerman, \& Johnson, 2005; Verquer, Beehr, \& Wagner, 2003). The longer an employee remains with an employer, the less likely advancement becomes, leading to reduced job satisfaction (Bartholomew, 1972; Gibson \& Klein, 1970; Stoikov, 1971). In some cases, experience has similar effects to tenure. Fewer opportunities in leadership positions may mean reaching a plateau in one's career, leading to lower job satisfaction (Cohen, 1993).

Some researchers claim that money has the largest effect on motivation (Tang \& Gilbert, 1995; Wagner, Rubin, \& Callahan, 1988). This is somewhat disputed by Herzberg et al. (1959) who assert that hygiene factors can cause dissatisfaction rather than factors that have motivational power. Herzberg, however, conceded that satisfaction with salary is a construct that could be part of the intrinsic factors. Opportunities for training and professional memberships may provide higher motivation compared to salary and bonuses in certain IT environments (Jyothi \& Ravindran, 2012; Shuck et al., 2014). Based on this discussion, we propose that: 
H4: Job characteristics have a positive association with job satisfaction for IT professionals in NZ.

\subsection{Job Satisfaction and Turnover Intent}

Research indicates a link between low job satisfaction and turnover intention. Lambert, Hogan, and Barton (2001) posit that the work environment plays a greater role in shaping job satisfaction than an individual's characteristics; this in turn influences turnover intent. This is supported by Kanwar, Singh, and Kodwani (2012) who found that those with higher job satisfaction among Indian IT professionals have lower turnover intent. Moreover, studies show that turnover reduces performance and can risk a period of low productivity (Gersick, 1988; Glebbeek \& Bax, 2004).

Some researchers maintain that not all turnover is detrimental for an organization and an optimal turnover rate exists (Abelson \& Baysinger, 1984; Wallace \& Gaylor, 2012). Others point to alternative explanations such as age (Bartholomew, 1972; Gibson \& Klein, 1970; Stoikov, 1971), concern about employability (Direnzo \& Greenhaus, 2011), psychological reasons (Lambert et al., 2001) and 'fit' with the organization (Kristof-Brown et al., 2005; Verquer et al., 2003) as contributors to turnover intent.

While research suggests that the source of turnover intention is multivariate in nature, motivation and job satisfaction play a significant role (Tzeng, 2002). Judge et al. (1998) contend that the relationship between job satisfaction and performance is more pronounced in complex professions, such as IT. In their meta-analysis, Griffeth, Hom and Gaertner (2000) identified that turnover actions, despite going through several withdrawal decisions and behaviours, are primarily initiated by job dissatisfaction (see also Mak and Sockel (2001)). They further point to work from Mone (1994), indicating that it is the most talented staff who are at risk.

This study extends the model (below) to incorporate turnover intent:

H5: Job satisfaction is negatively associated with turnover intent for IT professionals in NZ.

\subsection{The Smerek and Peterson Adjustment}

Smerek and Peterson (2007) developed and validated a survey instrument based on Herzberg's two-factor theory, which has been adopted here since it is comprehensive and takes account of respondents' personal and job characteristics. This allows our study to observe both general traits and situation-specific factors, a key recommendation by Locke and Latham (2004). While the original study measured satisfaction among university employees, others have replicated the instrument among hospital employees (Oladotun \& Öztüren, 2013) and social workers (Kundrátová, 2011). The current study validates Smerek and Peterson's (2007) updated model of Herzberg's theory by examining the relationship between motivation and personal and job characteristics, extends the model by testing the relationship between turnover intention and job satisfaction, and answers the call from Locke and Latham (2004) to investigate situation-specific contributors to theory by examining these factors with IT professionals in NZ.

Herzberg's two-factor theory explores many dimensions of job satisfaction other than pay, a key consideration for skilled IT professionals. Smerek and Peterson's (2007) study, using the two-factor theory as a basis, further allows for analysis of an individual's general traits through their personal characteristics, and situation-specific contributors in the form of job characteristics, and is ideally suited for providing an overarching theory for this study. The model is extended to include turnover intention as this has been identified in the literature as having a strong negative association with job satisfaction. Figure 1 summarises the hypotheses developed for this study. 


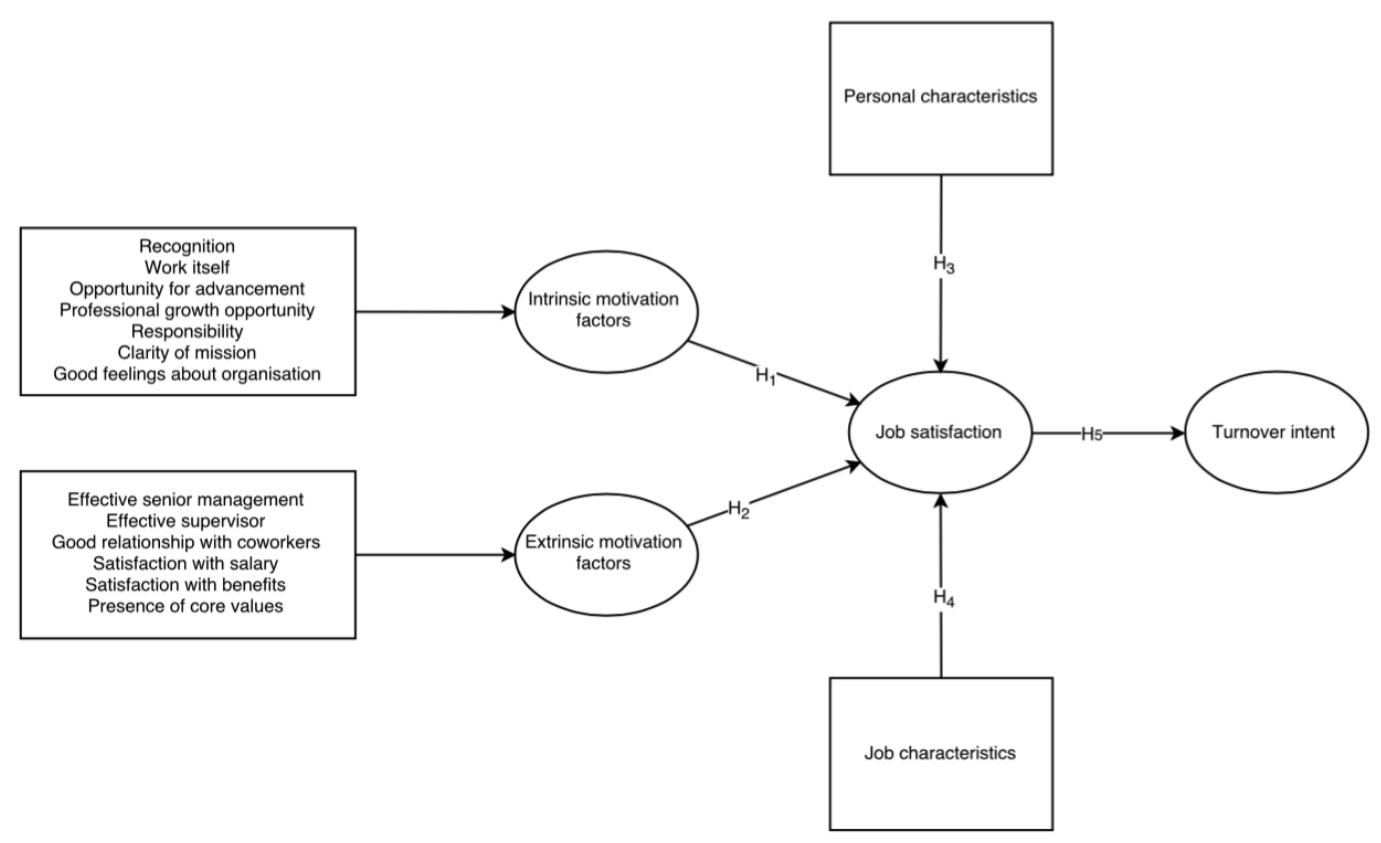

Figure 1: Conceptual model

\section{Methodology}

As this study aims to access a population who represent IT professionals in NZ, an online survey method was deemed the most efficient and effective approach (Cobanoglu, Warde, \& Moreo, 2001). The study used a modified model of Herzberg's two-factor study from Smerek and Peterson (2007). The items were adopted using a 10-point Likert scale as in the original instrument. Minor adjustments were made in wording the questions to provide the correct context (e.g. "the university" became "my organization"), place of birth and questions on minority status were replaced with place of birth (i.e. born in NZ?), and work unit classifications were made relevant to the IT profession. Turnover intent is measured using Singh and Loncar's (2010) method, an extension of Lum, Kervin, Clark, Reid, and Sirola's (1998) approach.

\subsection{Data Collection}

Immigration NZ (2015) estimates that the IT workforce in NZ numbers approximately 46,000 and Statistics NZ (2013a) puts it at just under 54,000. The IT profession does not require practitioners to belong to a licensing body, so the exact number and a definitive list of practitioners remain unknown. Research studies collecting data from organizations may not be uniformly well received by all, resulting in an undesirable skew towards some organizations (Bryman \& Bell, 2011). Therefore, the population was accessed through LinkedIn, a professional social networking site. The population is actively engaged in their professional domain. As the questionnaire was administered online, it provided a convenient method for encouraging participation.

Social network sites represent a new but increasingly accepted context in academic research design. For example, Robinson, Sinar and Winter (2014) used LinkedIn data to study organizational turnover. IT studies have also used social media - Barzilay and Urquhart (2014) used LinkedIn forums to study perceptions of code sample reuse in software development, and Benevenuto, Rodrigues, Cha, and Almeida (2012) used data from social networks including LinkedIn to study user navigation on the web.

While researchers recognise risks in using online survey data, especially around the selfreporting nature of social networks (Patton, 2012), there is less concern here because the intention was to use social media to access a population in a random manner, rather than to 
seek to verify their claimed credentials. The risk of misrepresentation was therefore no worse than for any other method of accessing a population.

\section{Analysis and Results}

The authors posted a survey invitation to the LinkedIn group entitled 'NZ IT Industry' (NZ IT industry, 2015), in line with Hewson and Laurent (2008). This group serves as a common space for anyone employed as an IT professional in NZ. It had 8,390 members at the time of this study. Among them, 250 group members were selected using the Microsoft Excel randomizer and invited to participate in the survey. A total of 157 responses were received (with a return rate of $62.8 \%$ ). Sixteen responses were removed due to some missing survey data, leading to an effective response rate of $56.4 \%(N=141)$.

Significantly, more males ( $n=107 ; 75.9 \%)$ responded than females ( $n=34 ; 24.1 \%)$. The number of women studying computer science and IT is seen to be dropping, with 1 in 5 IT students identifying as female (AbsoluteIT, 2015). Respondents were almost evenly split between those born in NZ $(n=69 ; 48.9 \%)$ and overseas $(n=72 ; 51.1 \%)$. Most were full-time employees $(n=117$; $83 \%)$. The majority of both NZ-born $(n=61 ; 88.4 \%)$ and overseas-born respondents $(n=56$; $77.8 \%)$ were employed full-time. The most widely represented age group was of 35-44 years $(n=47 ; 40.4 \%)$, followed by $45-54(n=42 ; 29.8 \%)$. More than three-quarters of respondents hold a Bachelor's degree $(n=52 ; 36.9 \%)$ or higher $(n=56 ; 39.7 \%)$. One-third has in excess of 20 years' experience $(n=47 ; 33.3 \%)$. More than one-third have been in their present role for less than two years $(n=52 ; 36.9 \%)$, while a considerable number $(n=17,12.1 \%)$ have been there for a decade or longer. Performance-based bonuses formed part of the remuneration package for $28.4 \%(n=40)$ of respondents, and a similar number belong to professional bodies $(n=39$, 27.7\%). Table 2 gives survey respondent details.

\begin{tabular}{|c|c|c|c|c|c|}
\hline Gender & $\mathbf{N}$ & $\%$ & Age & $\mathbf{N}$ & $\%$ \\
\hline Male & 107 & 75.9 & $<25$ & 5 & 3.5 \\
\hline \multirow{2}{*}{ Female } & 34 & 24.1 & 25 to 34 & 23 & 16.3 \\
\hline & & & 35 to 44 & 57 & 40.4 \\
\hline Qualification & $\mathrm{N}$ & $\%$ & 45 to 54 & 42 & 29.8 \\
\hline High School equivalent or less & 5 & $3 \cdot 5$ & 55 to 64 & 13 & 9.2 \\
\hline $\begin{array}{l}\text { Industry certification (i.e. } \\
\text { Microsoft, Oracle) }\end{array}$ & 28 & 19.9 & $>=65$ & 1 & .7 \\
\hline Bachelors degree & 52 & 36.9 & & & \\
\hline \multirow[t]{2}{*}{ Postgraduate degree or higher } & 56 & 39.7 & $\begin{array}{l}\text { Role - Overseas } \\
\text { Born }\end{array}$ & $\mathrm{N}$ & $\%$ \\
\hline & & & Self-employed or owner & 4 & 5.6 \\
\hline Role - NZ Born & $\mathrm{N}$ & $\%$ & Contract & 10 & 13.9 \\
\hline Self-employed or business owner & 2 & 2.9 & Part time employed & 2 & 2.8 \\
\hline Contract & 5 & 7.2 & Full time employed & 56 & 77.8 \\
\hline Part time employed & 1 & 1.4 & & & \\
\hline Full time employed & 61 & 88.4 & $\begin{array}{l}\text { Tenure (years) } \\
<2\end{array}$ & $\begin{array}{l}\mathrm{N} \\
52\end{array}$ & $\begin{array}{l}\% \\
36.9\end{array}$ \\
\hline Salary & $\mathrm{N}$ & $\%$ & $>=2$ and $<5$ & 44 & 31.2 \\
\hline 60,000 or less & 12 & 8.5 & $>=5$ and $<10$ & 28 & 19.9 \\
\hline 60,001 to 80,000 & 25 & 17.7 & $>=10$ & 17 & 12.1 \\
\hline 80,001 to 100,000 & 28 & 19.9 & & & \\
\hline 100,001 to 120,000 & 22 & 15.6 & Experience (years) & $\mathrm{N}$ & $\%$ \\
\hline & 29 & 20.6 & $<5$ & 15 & 10.6 \\
\hline \multirow[t]{2}{*}{ Higher than 150,000} & 25 & $17 \cdot 7$ & $>=5$ and $<10$ & 18 & 12.8 \\
\hline & & & $>=10$ and $<15$ & 21 & 14.9 \\
\hline
\end{tabular}




\begin{tabular}{|c|c|c|c|c|c|}
\hline $\begin{array}{l}\text { Bonus as part of } \\
\text { remuneration }\end{array}$ & $\mathbf{N}$ & $\%$ & $>=15$ and $<20$ & 40 & 28.4 \\
\hline Yes & 40 & 28.4 & $>=20$ & 47 & 33.3 \\
\hline \multirow[t]{4}{*}{ No } & 101 & 71.6 & & & \\
\hline & & & Prfs membership & $\mathrm{N}$ & $\%$ \\
\hline & & & Yes & 39 & 27.7 \\
\hline & & & No & 102 & 72.3 \\
\hline
\end{tabular}

Table 2: Descriptive statistics of the survey population

Analysis was undertaken using SPSS version 23, and WarpPLS version 5.0, a Structural Equation Modelling (SEM)-based Partial Least Squares (PLS) application. Unlike covariancebased SEM approaches, PLS is variance-based and has several advantages for this study (Rigdon, 2012). It can provide strong statistical output without assumptions about a normal distribution of the data (Hair, Sarstedt, Pieper, \& Ringle, 2012). Shapiro-Wilk and Kolmogorov-Smirnov tests of normality indicated that the study data were non-normal in their distribution.

PLS can also undertake SEM with a smaller sample size as compared to what is deemed acceptable for covariance-based SEM $(N>150)$ (Chin \& Newsted, 1999). This study used two orders of PLS-SEM, necessitated by its underlying model. The questionnaire from Smerek and Peterson (2007) allowed measurement of job satisfaction dimensions. A second abstraction was required to understand the concept of intrinsic and extrinsic motivation based on the dimensions from the observed variables. This was achieved through a second order construct (Ciavolino, 2012; Nitti \& Ciavolino, 2014; Petter, Straub, \& Rai, 2007).

The first order comprised reflective indicators, measuring similar aspects of a construct, and was expected to correlate with other indicators of the same construct. Abstract constructs such as intrinsic and extrinsic motivation were measured using the two-step modelling approach due to their formative nature, where the indicators within measured different aspects and are less likely to correlate highly (Ciavolino, 2012; Nitti \& Ciavolino, 2014). PLS is ideal for analysing a combination of reflective and formative constructs (Becker, Klein, \& Wetzels, 2012; Ringle, Sarstedt, \& Straub, 2012). Furthermore, it is an appropriate method and has been used for both developing and confirming theories (Chin, 1998; Urbach \& Ahlemann, 2010).

\subsection{Measurement Model - Reflective Indicators}

Prior to conducting Confirmatory Factor Analysis (CFA) and testing the structural model, Exploratory Factor Analysis (EFA) was performed to test sampling adequacy. The Principal Component Analysis (PCA) method with direct oblimin rotation was used. Keiser-MeyerOlkin's $(\mathrm{KMO})$ measure of sampling adequacy $(K M O=.879)$ and Bartlett's test of sphericity $(p<.001)$ indicated that data are suitable for factor analysis (Nixon \& Saphores, 2007; Wilson, Rodgers, Carpenter, Hall, Hardy, \& Fraser, 2004). The factors extracted explain $87 \%$ of the variation in the data (see Appendices Table A1).

Unidimensionality was retested after executing CFA, and required the removal of some indicators. The results of Rohatgi-SzÚkely (RS) and Klaassen-Mokveld-van Es (MKvE) tests of unidimensionality (refer to Table 3) further confirmed the identified factors can be relied upon to measure a single construct.

Cronbach's alpha (CA) and composite reliability (CR) were used to measure the internal consistency of the questions that comprise each construct within the model. The CA score for the remaining factors all exceeded .8 which is considered good, and .9 which is considered excellent (DeVellis, 2012). However, the CA score for effective supervisor, in excess of .95, may indicate a possible common method bias (Straub, Boudreau, \& Gefen, 2004). A full collinearity test was undertaken for effective supervisor. However, it found a Variance Inflation Factor (VIF) score of 3.017, lower than 3.3, the most conservative indicator of collinearity in the latent variable (Kock \& Lynn, 2012). Therefore, the common method bias risk is considered low. CR scores for all constructs were above the acceptable threshold of .7 (Nunnally \& Bernstein, 1994). Table 3 shows the internal consistency reliability measures for each construct. 


\begin{tabular}{|c|c|c|c|c|c|c|}
\hline Construct & \multicolumn{2}{|c|}{ 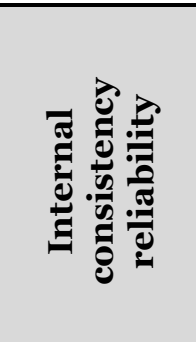 } & \multicolumn{2}{|c|}{ 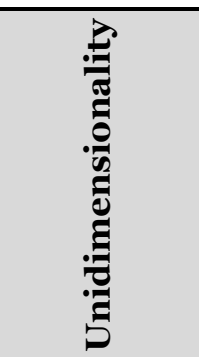 } & \multirow[t]{2}{*}{ 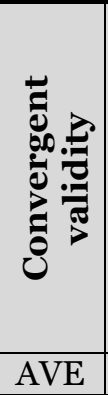 } & \multirow[t]{2}{*}{ 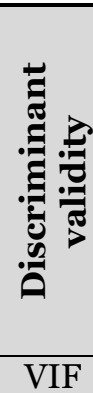 } \\
\hline & CR & CA & $\mathrm{RS}$ & MKvE & & \\
\hline Recognition & .883 & .834 & $\checkmark$ & $\sqrt{ }$ & .603 & 1.873 \\
\hline Work itself & .965 & .951 & $\checkmark$ & $\checkmark$ & .874 & 2.564 \\
\hline Opportunities for advancement & .881 & .819 & $\checkmark$ & $\checkmark$ & .651 & 2.371 \\
\hline $\begin{array}{l}\text { Professional growth } \\
\text { opportunities }\end{array}$ & .935 & .913 & $\checkmark$ & $\checkmark$ & .744 & 2.439 \\
\hline Responsibility & .938 & .918 & $\checkmark$ & $\checkmark$ & .753 & $3 \cdot 381$ \\
\hline $\begin{array}{l}\text { Good feelings about } \\
\text { organization }\end{array}$ & .955 & .941 & $\checkmark$ & $\checkmark$ & .810 & 2.583 \\
\hline Clarity of mission & .936 & .917 & $\checkmark$ & $\checkmark$ & .711 & 2.939 \\
\hline Effective senior management & .973 & .958 & $\checkmark$ & $\checkmark$ & .922 & 2.243 \\
\hline Effective supervisor & .988 & .987 & $\checkmark$ & $\checkmark$ & .844 & 3.017 \\
\hline Good relations with co-workers & .937 & .922 & $\checkmark$ & $\checkmark$ & .651 & 1.895 \\
\hline Satisfaction with salary & .878 & .807 & $\checkmark$ & $\checkmark$ & .653 & 2.105 \\
\hline Satisfaction with benefits & .910 & .865 & $\checkmark$ & $\checkmark$ & .718 & 2.019 \\
\hline Presence of core values & .938 & .901 & $\checkmark$ & $\checkmark$ & .836 & 2.262 \\
\hline Job satisfaction & .958 & .934 & $\checkmark$ & $\checkmark$ & .884 & 3.922 \\
\hline Turnover intent & .831 & .723 & $\checkmark$ & $\checkmark$ & .559 & 1.947 \\
\hline
\end{tabular}

Table 3: Reliability and validity of constructs

Indicator reliability is measured by the correlation between the latent variables and the square root of the average variance explained (AVE). All indicators have a value of greater than .707 and have the highest AVE value for their own construct, thereby explaining more than half of the indicator's variance. As a result, indicator reliability has been established (refer to Table 4) (Chin, 1998).

Convergent validity is measured with the Fornell and Larcker (1981) criterion. It requires each latent variable to have an AVE value of .500 or higher, explaining at a minimum half of the variances of its indicators. This condition is met by the analysis (refer to Table 3).

Discriminant validity is established through examination of VIF from a full collinearity test. The construct for job satisfaction scored the highest value of 3.922 (refer to Table 3). VIFs below 5 are generally accepted as reliable evidence of low collinearity, thereby confirming discriminant validity (Hair, Black, Babin, \& Anderson, 2010). 


\begin{tabular}{|c|c|c|c|c|c|c|c|c|c|c|c|c|c|c|c|}
\hline & REC & WRK & ADV & GTH & RSP & GFO & MIS & SMG & SPV & CWR & SAL & BEN & VAL & SAT & TRN \\
\hline REC & $(.777)$ & & & & & & & & & & & & & & \\
\hline WRK & .460 & $(.935)$ & & & & & & & & & & & & & \\
\hline $\mathrm{ADV}$ & .558 & .494 & $(.807)$ & & & & & & & & & & & & \\
\hline GTH & .417 & .523 & .532 & $(.862)$ & & & & & & & & & & & \\
\hline RSP & .521 & .606 & .509 & .565 & $(.868)$ & & & & & & & & & & \\
\hline GFO & .474 & .502 & .574 & .549 & .637 & $(.900)$ & & & & & & & & & \\
\hline MIS & .504 & .601 & .555 & .541 & .724 & .636 & $(.843)$ & & & & & & & & \\
\hline SMG & .375 & .356 & .508 & .449 & .548 & .516 & .547 & $(.960)$ & & & & & & & \\
\hline SPV & .441 & .555 & .543 & .675 & .679 & .576 & .581 & .471 & $(.924)$ & & & & & & \\
\hline CWR & .443 & .481 & .365 & .458 & .482 & .518 & .545 & .406 & .492 & $(.830)$ & & & & & \\
\hline SAL & .484 & .417 & .448 & .404 & .564 & .472 & .549 & .534 & .420 & .408 & $(.901)$ & & & & \\
\hline BEN & .242 & .278 & .418 & .447 & .417 & .484 & .433 & .447 & .305 & .226 & .538 & $(.847)$ & & & \\
\hline VAL & .356 & .352 & .529 & .333 & .458 & .503 & .506 & .639 & .447 & .403 & .407 & .480 & $(.914)$ & & \\
\hline SAT & .442 & .710 & .499 & .556 & .713 & .637 & .607 & .466 & .656 & .455 & .560 & .408 & .495 & $(.940)$ & \\
\hline TRN & -.310 & -.336 & -.487 & -.497 & -.423 & -.487 & -.352 & -.433 & -.592 & -.293 & -.398 & -.276 & -.370 & -.613 & $(.809)$ \\
\hline
\end{tabular}

Notes:

\begin{tabular}{|llllll|}
\hline REC & Recognition & WRK & Work itself & ADV & Opportunities for advancement \\
GTH & Professional growth opportunities & GFO & Good feelings for organization & RSP & Responsibility \\
MIS & Clarity of mission & SMG & Effective senior management & SPV & Effective supervisor \\
CWR & Good relations with co-workers & SAL & Satisfaction with salary & BEN & Satisfaction with benefits \\
VAL & Presence of core values & SAT & Job satisfaction & TRN & Turnover intent \\
\hline
\end{tabular}

Table 4: Correlation between latent variables and square root of AVE in diagonal 


\subsection{Measurement Model - Formative Indicators}

Indicator validity is measured by a combination of significance weight and VIFs. Each indicator for the formative constructs and control variables demonstrates a higher level of significance than the prescribed .05 (Efron \& Tibshirani, 1993). Additionally, all of the individual indicators for the formative constructs, overall constructs and control variables display VIFs less than 5 as Intrinsic Motivation being 4.719 and Extrinsic motivation being 3.470 (refer to Appendices Table A2). Consequently, multicollinearity is not a major threat to indicator validity (Diamantopoulos \& Siguaw, 2006). It can be concluded that the indicators for the second order PLS-SEM are valid.

\subsection{Structural Model - Analysis}

Explained variance of constructs relative to its total measure is used to assess the first part of model validity. The model explains moderate to substantial variance for job satisfaction $\left(R^{2}=.61\right)$ and turnover intent $\left(R^{2}=.38\right)$ (Chin, 1998).

Path coefficients between the latent variables further assess the model's fit. The only sign with a negative valence is that of turnover intent, which is expected based on prior literature (Kanwar et al., 2012; Griffeth et al., 2000). The path from extrinsic motivation $(\beta=.17, p=.02)$ and intrinsic motivation $(\beta=.61, p<.001)$ to job satisfaction, and from job satisfaction to turnover intent $(\beta=.61, p<.001)$ all indicate a significant impact in the model. Further tests on robustness through using a holdout sample of around $70 \%$ of the original sample to retest the findings (Hair, Ringle, \& Sarstedt, 2013) did not contradict any major conclusions from the full sample.

Non-response bias was tested as a threat to external validity of the study by comparing the early responders with later ones. It is estimated that the later respondents (who answered after the final reminder was sent - Barclay, Todd, Finlay, Grande, \& Wyatt, 2002) are closer to nonrespondents compared to those who responded early (Armstrong \& Overton, 1977). The Welch $\mathrm{F}$ Test was measured as $3.123(\mathrm{p}<.05)$ for age and $3.804(\mathrm{p}<.05)$ for income while BrownForsythe was measured as 2.903 for age and 3.130 for income (for both $\mathrm{p}<.05$ ). The results indicated there were no significant differences in gender and qualifications but there are for age and income (refer to Appendices Table A3).

Later respondents were more likely to be younger $(M=2.92, S D=1.02)$ and have a higher income $(M=3.84, S D=1.94)$ compared to early respondents $(M=3.37, S D=1.02$ and $M=3.70$, $S D=1.45$ respectively). Statistics NZ (2013b) data indicate that the proportion of males $(75.8 \%)$ to females (24.2\%), and full-time employees (83.9\%) align with industry averages. Regardless of the survey design, an element of non-response bias cannot be avoided (Dillman, 1991).

Based on the external validity tests and publicly-available information, the study participants can be claimed to be representative of the target population (Barclay et al., 2002). Our results should be read in the knowledge that younger and higher paid IT professionals may be marginally under-represented in the sample.

\subsection{Structural Model-Results}

First order PLS-SEM was undertaken with 15 latent variables from 78 observed variables. All latent variables in the first order are reflective variables, measuring different aspects of the same construct (Becker et al., 2012). The contribution of individual factors was analysed for their effect on job satisfaction and subsequently turnover intention. The model explained 87\% of the variance in job satisfaction.

Second order PLS-SEM was undertaken with latent variables leading to job satisfaction grouped into two sub-categories to form reflective latent variables - intrinsic and extrinsic motivation. The latent variables of recognition, work itself, opportunity for advancement, professional growth opportunity, responsibility, good feeling about organization, and clarity of mission constituted intrinsic motivation, while effective senior management, effective supervisor, good relationship with co-workers, satisfaction with salary, satisfaction with 
benefits, and presence of core values comprised extrinsic motivation (Smerek \& Peterson, 2007; Volkwein \& Zhou, 2003; Spencer, 1997).

Additionally, observed control variables for demographic and job characteristics were included as control variables. A two-step second order PLS-SEM model was used. Figure 2 represents the conceptual model tested in the study.

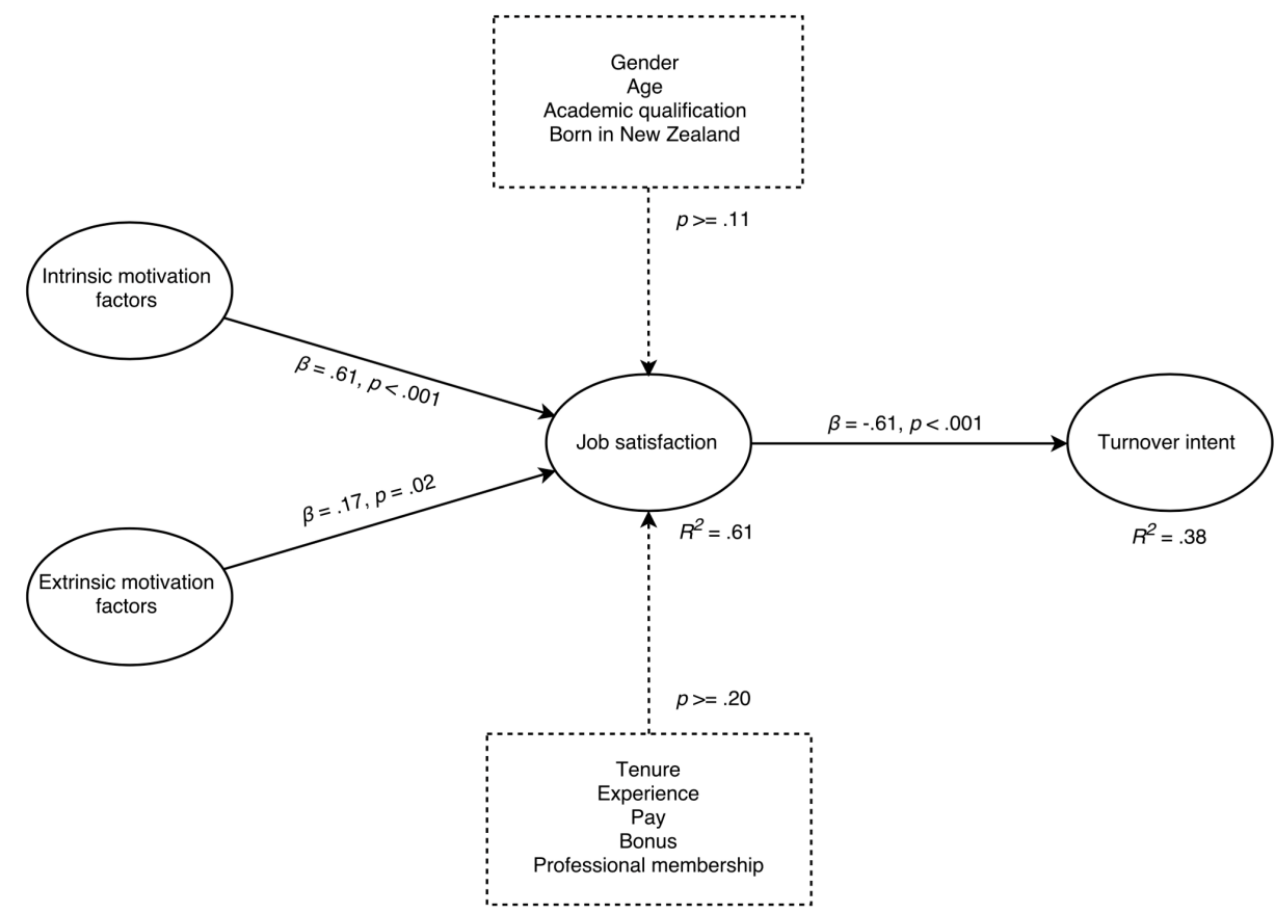

Figure 2: Conceptual Model with second order PLS-SEM

The model explains $61 \%$ of the variation in job satisfaction. Extrinsic motivation factors have a marginal positive association $(\beta=.17, p=.02)$ with job satisfaction. In comparison, intrinsic motivation factors have a much stronger positive association $(\beta=.61, p<.001)$. The influence of demographic and job characteristics on motivation was statistically insignificant. The model explains $38 \%$ of the variation in turnover intent and has a strong negative association with job satisfaction $(\beta=-.61, p<.001)$.

\section{Discussion}

The model used in the study explained $61 \%$ of the variation in job satisfaction, and $38 \%$ of the variation in turnover intention. This aligns with previous studies in the field of information systems research by Moqbel, Nevo, and Kock (2013) and Stuart, Verville, and Taskin (2012). The model $R^{2}$ for job satisfaction was .60 without the presence of control variables. With the control variables added, there was a positive $\left(R^{2}=.61\right)$ although statistically insignificant change. Contribution to turnover intent $\left(R^{2}=.38\right)$ was unchanged with or without the presence of the control variables in the model.

This study, like previous ones, found a strong negative association between job satisfaction and turnover intent ( $\beta=-.61, p<.001$ ) (Alniaçik, Alniaçik, Erat, \& Akçin, 2013; Kanwar et al., 2012). Judge et al. (1998) concluded there is a significant correlation between job satisfaction and performance in complex roles, a relationship that fits the IT profession. Therefore, the need for management to ensure high levels of job satisfaction to retain top talent is obvious.

The study found a marginal positive association of extrinsic factors towards job satisfaction $(\beta=.17, p=.02)$. The association of intrinsic motivation factors with job satisfaction is strong $(\beta=.61, p<.001)$, and statistically more significant. It is noteworthy that there was more than a three-fold difference in effect between association of extrinsic and intrinsic factors to job 
satisfaction based on path coefficients. These results are similar to those supporting the twofactor theory (Herzberg et al., 1959).

The study results did not support hypotheses regarding the positive effects of demographic or job characteristics on motivation. Second order PLS-SEM indicated that the effects of gender, age, academic qualifications, tenure, experience, pay, bonuses, and professional membership were statistically insignificant. This result was further substantiated by a holdout sample of $70 \%$ of the total response showing near-identical results (Hair et al., 2012). This contradicts previous findings from other researchers (e.g. Glenn et al., 1977).

This contradiction must be read in light of the recent trend whereby researchers discount or re-interpret associations of personal characteristics in particular. In their model for analysing job satisfaction and organizational commitment, Collie, Shapka, Perry and Martin (2015) did not include personal characteristics. Lange (2012) showed that the reason for higher job satisfaction among the self-employed was due to autonomy and independence, rather than personal characteristics, as had been thought.

The results indicated that organizations can be confident that initiatives to increase or sustain job satisfaction levels are likely to result in similar outcomes, regardless of personal or job characteristics of staff. Analysis of the first order PLS-SEM indicated that satisfaction with salary has a positive association with job satisfaction $(\beta=.14, p=.05)$. This is not a surprise, as salary was only classified as a marginal extrinsic factor by Herzberg et al. (1959) although some previous studies have concluded that remuneration has a large effect on motivation (Tang \& Gilbert, 1995).

Significantly, the nature of IT professionals' work appears to influence job satisfaction most. This is demonstrated by the work itself showing the highest positive association $(\beta=.39$, $p<.001)$ alongside responsibility $(\beta=.20, p<.01)$. When this is taken into consideration with the only other statistically-significant association with job satisfaction being effective supervision $(\beta=.23, p<.01)$, a pattern emerges. Interesting and challenging work, coupled with responsibility, and the belief that supervisors are willing to encourage such, appear to be the best predictors of job satisfaction, a view shared by others (Judge et al., 1998; Saari \& Judge, 2004).

One surprising finding was the lack of positive association of advancement or professional growth opportunities. Some previous studies indicate that IT professionals may be more motivated by these factors than even salary (Jyothi \& Ravindran, 2012; Shuck et al., 2014). However, no such evidence was found here. How an IT professional feels about the firm or its clarity of mission does not impact on individual motivation. Taking into account lack of impact on good relations with co-workers, our findings support Rajagopal and Abraham (2009) who contend that the hierarchy of needs for IT professionals goes from basic needs to higher order, and skips some of the social dimensions.

Responses based on the control variables on the dimensions of job satisfaction also indicated interesting patterns. Females are happier than males on most intrinsic motivation factors. This can be explained by the expectation hypothesis which states that, although both men and women desire the same or similar features in their jobs, the lower expectations that women have make them more satisfied in their workplace (Lambert, 1991). However, additional research is required to further clarify the relationship between gender and intrinsic motivation, and whether the expectation hypothesis or value hypothesis holds for IT professionals in the NZ context. Notwithstanding this, higher satisfaction with salary for females was a surprising finding, contradicting some previous studies (Clark, 1997). Absolute and relative pay can provide a plausible explanation as two determinants of satisfaction with salary (Taylor \& Vest, 1992). By comparing their salaries with other women who work in other departments or organizations, these women may appreciate their pay more (Jung, Moon, \& Hahm, 2007).

Additionally, women form a smaller portion of the IT workforce (Chabrow, 2007). Belonging to a small, skilled and highly-paid workforce may be satisfactory to women, especially if they are earning equal to or more than they expected to earn (Oshagbemi \& Hickson, 2003) in the 
NZ IT industry. Another reason for salary satisfaction may concern the level of women's seniority in their organization (Oshagbemi \& Hickson, 2003). According to Andrews and Henry (1963), there is a positive association between organizational level and satisfaction with salary. Satisfaction is observed to noticeably drop off along many dimensions as people age. However, this does not appear to translate into an increased turnover intent.

There were no statistically significant differences in the responses based on qualification and whether people were born in NZ or overseas. Job characteristic factors - tenure, experience, salary, bonus and professional membership - demonstrated little or no differences in the response pattern for any of the factors. Those with higher salary or professional membership are happier with their salary than others - this is unsurprising given previous research (Tang \& Gilbert, 1995; Wagner et al., 1988).

The lack of statistically significant differences in job satisfaction based on country of birth was mildly surprising. In a recent study in Australia, Kifle, Kler and Shankar (2016) found significant differences in job satisfaction between those born in Australia and others. This difference is even more pronounced when the immigrant comes from a non-English speaking background. Johnson and Johnson (2000) found similar results in the US and concluded that it reflects how new migrants have to restart their careers at a lower level than in their native environments. Kifle et al. (2016) noted that this effect reduces with time. This study did not control for the duration that non-NZ born IT professionals had been in NZ.

\subsection{Implications for Practitioners}

What motivates IT workers should be of interest to management of both IT firms and other organizations that employ IT professionals, as well as to policy-makers responsible for delivering improved outcomes for their country through, for example, strengthening tertiary education and attracting suitably-skilled migrants (MBIE, 2015). The relative contributions of extrinsic and intrinsic factors to job satisfaction have implications for the results of job satisfaction surveys in the IT sector. This study found that intrinsic motivation factors have far more influence on one's job satisfaction than extrinsic factors. To undertake more accurate satisfaction surveys, organizations must invest significantly more in understanding the intrinsic motivation of their IT professionals by ensuring that satisfaction surveys in particular explore the nature of the work undertaken by staff and the responsibility associated with their roles.

The results showing that those born in NZ and overseas did not differ statistically in their view of motivation have implications for employers. There is an acute skills shortage in the industry sector (NZTech, 2016) that requires concerted action from policy-makers to improve tertiary education and to perhaps increase the number of international students studying in the information systems/technology discipline. In the short term, however, the shortage will have to be met by skilled migrants (MBIE, 2015).

Within organizations, given our findings, consideration might be given to the following: i) firms should focus on developing and maintaining a motivated workforce to ensure top talent is retained. A lack of job satisfaction is what drives turnover intent; ii) firms should focus on the nature of the jobs that IT professionals undertake if they wish to foster a motivated workforce. What they do and how much responsibility is afforded to them are the key predictors of job satisfaction; iii) firms should train supervisors to provide an empowering environment for IT professionals. Perceptions of how enabling supervisors are contributes significantly to job satisfaction; iv) firms should offer competitive salaries to retain top talent. While salary is not as strong a predictor of job satisfaction as the nature of the job, responsibility and satisfaction with supervisor, it still shows a positive association; and v) firms should not hesitate to employ IT professionals born outside of NZ. There are no significant differences between the two.

These recommendations might be viewed in relation to the specificities of the NZ IT sector. The vast majority of NZ firms, those in the IT sector included, are small entities with relatively unsophisticated HR approaches. Their development in terms of HR functions might be 
described as embryonic and in many cases uncharted (Arrowsmith \& Parker, 2012); there is little to suggest that HR thinking has been deeply integrated into many NZ firms' strategic planning. Whilst this partly reflects resourcing and structural issues, a recalibrated understanding of HR's significance to employee outcomes such as turnover intention, productivity and long-term measures of corporate performance (e.g. Huselid, 1995) would encourage tailored and more effective organizational and employment relations responses wherein managers encourage the development of satisfying job roles and of highly-motivated, autonomous staff. In NZ, this might include greater utilisation of outsourced HR professional services and/or of shared HR services by small IT firms.

Furthermore, NZ's IT sector - using an OECD definition of ICT and high-tech manufacturing - employs $5 \%$ of the national workforce. Another one-fifth or 20,000 are tech workers in other sectors. HR strategies thus need to take account of the sector (and within-sector) location of IT workers, and particularly, the characteristics of the specific jobs, career paths and opportunities in those areas. The NZ tech sector produced NZ\$32.2 billion in total output and $9 \%$ of NZ's exports in 2015 (NZTech, 2016). NZ's IT sector is increasingly involved on the world stage, making effective people management in local organizations crucial. NZ-based IT professionals can look overseas if they are not sufficiently motivated by the work options available in NZ; concomitantly, HR strategy in NZ IT firms needs to increasingly consider how engagement with overseas parties shapes their corporate mission and goals, and by extension, local work and job design and employment conditions.

The world is arguably less concerned with NZ's size, location and organizational profile, and more with its innovation, quality and ease of doing business. Cohesion on such, combined with sectoral agility on account of its relatively small size and 'can do' approach to innovation and work challenges, may combine with connectivity that negates geographical distance and NZ's neutrality in geopolitical terms, to emphasise competitive advantage.

\subsection{Implications for Methodology and Theory}

One criticism of Two-Factor Theory concerns its method-bound nature. Most successful replications have used the critical incident method, introducing natural ego defence into the equation (Vroom, 1966). Very few questionnaire-based studies have replicated similar results (House \& Wigdor, 1967). This study uses an online, self-completion questionnaire method, yet the results parallel the two-factor theory and therefore can add some weight in relieving its method-bound criticism. This study also contributes to an understanding of determinants of job satisfaction by examining IT professionals who are unique in their motivational drivers in a country with some unique HR practices.

The use of LinkedIn also extended the traditional means of data collection by reaching populations in a more convenient and cost effective way. With the changing nature of content consumption and communication, this is an important consideration for future studies. This mechanism can also potentially remove geographical barriers in studies and allow for larger samples. The use of social media profiles can also allow access to wider information about participants and their behaviour.

\subsection{Limitations}

While external validity tests indicated that the study participants are generally representative of IT workers in NZ, we note that the questionnaire was more suited to employees of traditionally-defined organizations, rather than individual contractors or start-ups, who may have different motivators. As this sector represents nearly $13 \%$ of the overall IT workforce (Statistics NZ, 2013b), future studies will need to adjust the model to overcome this limitation.

There were also some differences between early and late responders. Later responders were younger in age and had a higher salary. As later responders were closer to non-responders (Armstrong \& Overton, 1977), they may be under-represented among the respondents.

Diversity of employee characteristics and thus consumers in NZ is one of the highest in the world (Parker, 2013). Yet, our study shows women are under-represented in the IT sector 
despite considerable opportunities (e.g. NZ Human Rights Commission, 2012). Following the 1986 Immigration Policy Review, there has been sustained growth in the number of skilled Asians entering highly-skilled occupations in NZ in areas of labour shortage, including in the IT sector (Badkar \& Tuya, 2010).

Future studies might further examine the diversity of the sector's workforce to better understand the context for developing meaningful diversity/inclusivity management and 'best fit' HR strategies that can progress competitive organizational behaviour. It has been argued that "the discourse of managing diversity, emerging from the US management literature, cannot be simply mapped on to organizations in other cultural contexts" (Jones, Pringle \& Shepherd, 2000: 364). Diversity issues (including a sense of 'self-sufficiency' and innovative spirit) reflect cultural assumptions that are specific to NZ, and require a multi-voiced discourse to focus attention on dynamic local demographics, cultural and political differences.

\section{Conclusion}

IT firms wishing to remain competitive must prioritise the acquisition and retention of talent (Dobbs, Koller, \& Ramaswamy, 2015). This can only be done when they understand what motivates talent; otherwise they risk becoming strategically irrelevant (Guttentag, 2015). Even where strategic irrelevance is not an imminent threat, a lack of motivation compromises performance (Kanwar et al., 2012).

The rapidly changing nature of organizations and the role that IT plays in shaping them, coupled with NZ's vision of becoming a knowledge economy, means the benefits of a motivated workforce are significant to both firms and policy-makers. The study findings indicate that the best predictor of motivation for the NZ IT professionals is the nature of the work they undertake, alongside their perception of responsibility afforded to them, and their supervisor's commitment to ensuring such an environment. To a lesser extent, salary also plays a role in job satisfaction.

Surprisingly, there was no statistically significant evidence of opportunities for advancement, professional growth opportunities, or recognition playing a role in job satisfaction. It also emerged that females are more satisfied than males on most dimensions of job satisfaction. While satisfaction drops off as people age, it does not appear to lead to increased turnover intention. Academic qualifications, whether a person is born in NZ, tenure, experience, salary, bonuses, and professional membership did not play a significant role in the responses. Figure 3 summarises the findings.

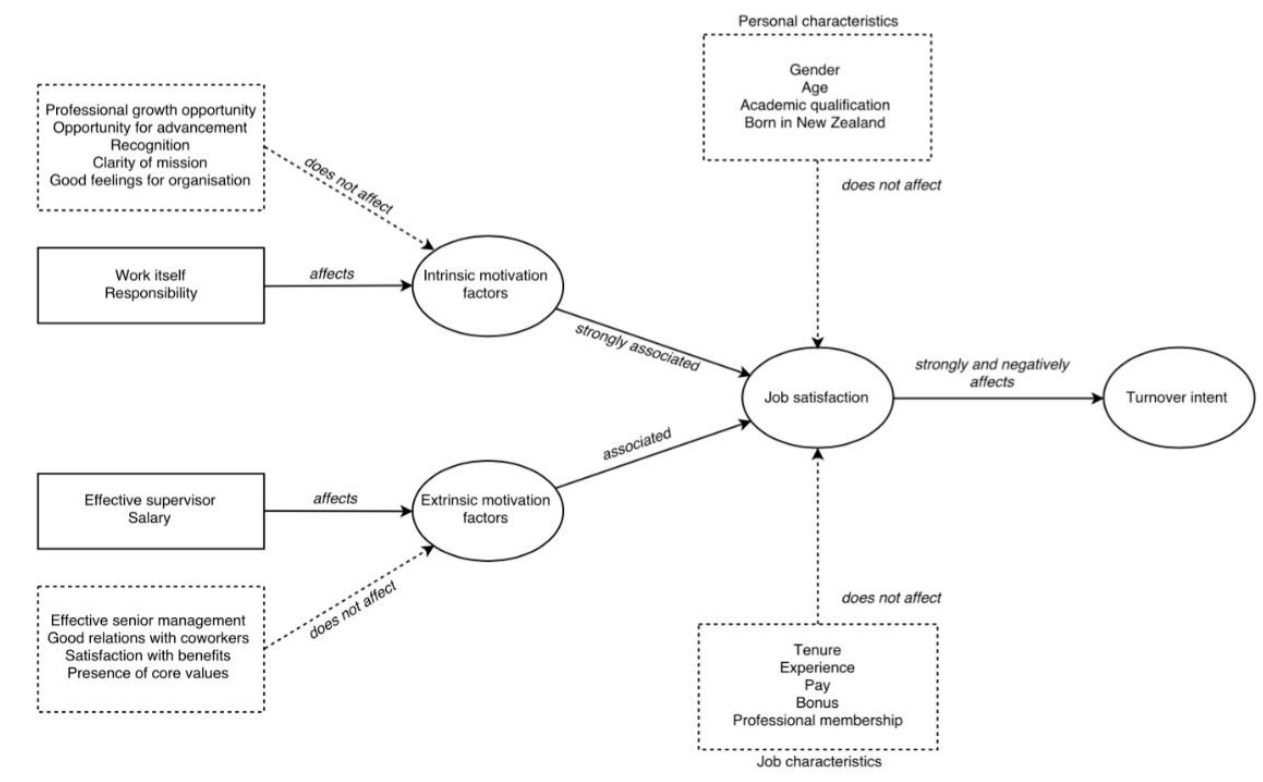

Figure 3: Summary of findings 
The absence of studies on job motivation in the NZ IT sector helped to motivate this study. One plausible explanation for the lack of empirical work may concern the blurred definition of the IT sector in this small nation. In NZ, an extensive body of studies on the IT sector hail from different economies. Furthermore, the IT sector in NZ exhibits some unique attributes including many small and micro-entities; a relative absence of sophisticated, in-house HR functions/departments and limited use of outsourced HR capacity; and a somewhat uniquely strong sense of entrepreneurial spirit among NZ workers generally. Additional challenges are posed by the high level of diversity of the NZ IT workforce.

Furthermore, there may be a distinct set of motivators between the various different subgroups. Our sample size did not allow for PLS-SEM to be repeated on sub-groups. A larger sample size may allow for the examination of tendencies within sub-groups so as to shed additional light on this. This may also lead to reduced risk of possible non-response bias from younger and higher-paid professionals.

This study adopts and validates a modified version of Herzberg's well-known two-factor theory for the NZ setting. Future studies could examine the theory in other sectors or enhance the theoretical model by including other constructs such as performance. Such studies can provide support to the universality or otherwise of Herzberg's theory. Researchers could also test the model for global companies or virtual companies with distributed workforces to discover whether theory can explain the motivation for this type of workforce. An opportunity exists to undertake a comprehensive qualitative study to gain further insight into the results; quantitative analysis in this study did not find statistically significant effects for personal and job characteristics.

\section{References}

Abelson, M. A., \& Baysinger, B. D. (1984). Optimal and dysfunctional turnover: Toward an organizational level model. Academy of Management Review, 9(2), 331-341. doi: 10.5465/AMR.1984.4277675

AbsoluteIT. (2015). Is NZ's gender gap in tech as bad as we think? 29 July. Retrieved on 7 February from https://www.absoluteit.co.nz/2015/o7/nzs-gender-gap-in-tech-bad-aswe-think/

Adams, J. S. (1965). Inequity in social exchange. In L. Berkowitz (Ed.), Advances in experimental social psychology (Vol. 2, pp. 267-299). New York: Academic Press.

Alderfer, C. P. (1969). An empirical test of a new theory of human needs. Organizational Behavior \& Human Performance, 4(2), 142-175.

Allen, N. J., \& Meyer, J. P. (1993). Organizational commitment: Evidence of career stage effect. Journal of Business Research, 26(1), 49-61.

Alniaçik, E., Alniaçik, Ü., Erat, S., \& Akçin, K. (2013). Does person-organization fit moderate the effects of affective commitment and job satisfaction on turnover intentions? Social and Behavioral Sciences, 99(6), 274-281. doi: 10.1016/j.sbspro.2013.10.495

Andrews, I. R., \& Henry, M. M. (1963). Management attitudes toward pay. Industrial Relations: A Journal of Economy and Society, 3(1), 29-39.

Anjali, K. T., \& Anand, D. (2015). Intellectual stimulation and job commitment: A study of IT professionals. IUP Journal of Organizational Behavior, 14(2), 28-41.

Armstrong, J. S., \& Overton, T. S. (1977). Estimating non response bias in mail surveys. Journal of Marketing Research, 14(3), 396-402.

Arrowsmith, J., \& Parker, J. (2012). Good Work and Good Workplaces. In R. Ryan and J. Bryson (eds), Critical Perspectives on HRM: A Primer (chapter 7, pp172-203). Auckland: Pearson Educational. 
Badkar, J. \& Tuya, C. (2010). The Asian workforce in New Zealand's economy. Published paper in the Labour, Employment and Work in New Zealand conference proceedings, Wellington. $\quad$ Retrieved on 6 February 2017 from file:///C:/Users/irruja/Downloads/1721-2198-1-SM.pdf

Bandura, A. (1977). Self-efficacy: Toward a unifying theory of behavioral change. Psychological Review, 84(2), 191-215. doi: 10.1037/0033-295X.84.2.191

Bandura, A. (2000). Cultivate self-efficacy for personal and organizational effectiveness. In E. A. Locke (Ed.), The Blackwell Handbook of Principles of Organizational Behavior (pp. 120-136). Malden, MA: Blackwell Publishers Ltd.

Barclay, S., Todd, C., Finlay, I., Grande, G., \& Wyatt, P. (2002). Not another questionnaire! Maximizing the response rate, predicting non-response and assessing non-response bias in postal questionnaire studies of GPs. Family Practice, 19(1), 105-111.

Bartholomew, D. J. (1972). The effect of changes in quits and hires on the length-of-service composition of employed workers: A comment on Stoikov's paper. British Journal of Industrial Relations, 10(1), 130-133.

Barzilay, O., \& Urquhart, C. (2014). Understanding reuse of software examples: A case study of prejudice in a community of practice. Information and Software Technology, 56(12), 16131628. doi: 10.1016/j.infsof.2014.02.013

Becker, J.-M., Klein, K., \& Wetzels, M. (2012). Hierarchical latent variable models in PLS-SEM: Guidelines for using reflective-formative type models. Long Range Planning(45), 359394. doi: 10.1016/j.lrp.2012.10.001

Beecham, S., Baddoo, N., Hall, T., Robinson, H., \& Sharp, H. (2008). Motivation in Software Engineering: A systematic literature review. Information and Software Technology, 50, 860-878. doi: 10.1016/j.infsof.2007.09.004

Benevenuto, F., Rodrigues, T., Cha, M., \& Almeida, V. (2012). Characterizing user navigation and interactions in online social networks. Information Sciences, 195(July), 1-24. doi: 10.1016/j.ins.2011.12.009

Boxall, P., Macky, K., \& Rasmussen, E. (2003). Labour turnover and retention in New Zealand: The causes and consequences of leaving and staying with employers. Asia Pacific Journal of Human Resources, 41(2), 196-214.

Bruce, G. D., Bonjean, C. M., \& Williams Jr., J. A. (1968). Job satisfaction among independent businessmen. Sociology and Social Research, 52(3), 195-202.

Bryman, A., \& Bell, E. (2011). Business research methods (3rd ed.): Oxford University Press.

Carrell, M. R., \& Elbert, N. F. (1974). Some personal and organizational deterinants of job satisfaction of postal clerks. Academy of Management Journal, 17(2), 368-373. doi: $10.2307 / 254991$

Chabrow, E. (2007). Numbers show big decline of women in IT. CIO Insight.

Chin, W. W. (1998). The partial least squares approach to structural equation modeling. In G. A. Marcoulides (Ed.), Modern methods for business research (pp. 1295-1336). Mahwah, NJ: Lawrence Erlbaum Associates.

Chin, W. W., \& Newsted, P. R. (1999). Structural equation modeling analysis with small samples using partial least squares. In R. Hoyle (Ed.), Statistical strategies for small sample research (pp. 1307-1341). Thousand Oaks, CA: Sage Publications.

Ciavolino, E. (2012). General distress as second order latent variable estimated through PLSPM approach. Electronic Journal of Applied Statistical Analysis, 5(3), 458-464. doi: 10.1285/i20705948v5n3p458 
Clark, A. E. (1997). Job satisfaction and gender: Why are women so happy at work? Labour Economics, 4(4), 341-372.

Cobanoglu, C., Warde, B., \& Moreo, P. J. (2001). A comparison of mail, fax and web-based survey methods. International Journal of Market Research, 43(4), 441.

Cohen, A. (1993). Work commitment in relation to withdrawal intentions and union effectiveness. Journal of Business Research, 26(1), 75-90.

Collie, R. J., Shapka, J. D., Perry, N. E., \& Martin, A. J. (2015). Teachers' psychological functioning in the workplace: Exploring the roles of contextual beliefs, need satisfaction, and personal characteristics. Journal of Educational Psychology. doi: 10.1037/eduooooo88

Deci, E. L., Koestner, R., \& Ryan, R. M. (1999). A meta-analytic review of experiments examining effects of extrinsic rewards on intrinsic motivation. Psychological Bulletin, 125(6), 627-668. doi: 10.1037/0033-2909.125.6.627

DeVellis, R. F. (2012). Scale development: Theory and applications. Los Angeles, CA: Sage.

Diamantopoulos, A., \& Siguaw. (2006). Formative versus reflective indicators in organizational measure development: A comparison and empirical illustration. British Journal of Management, 17(4), 263-282.

Dillman, D. A. (1991). The design and administration of mail surveys. Annual review of sociology. 17(1), 225-249

Direnzo, M. S., \& Greenhaus, J. H. (2011). Job search and voluntary turnover in a boundary less world: A control theory perspective. The Academy of Management Review, 36(3), 567-589.

Dobbs, R., Koller, T., \& Ramaswamy, S. (2015). The future and how to survive it: Corporate profits are beginning a long slide. Prepare for leaner times. Harvard Business Review, 93(10), 48-62.

Efron, B., \& Tibshirani, R. (1993). An introduction to the bootstrap. New York: Chapman Hall.

Ferratt, T. W., \& Short, L. E. (1986). Are information systems people different? An investigation of motivational differences. Management Information Systems Quarterly, $10(4), 377-387$.

Fornell, C., \& Larcker, D. F. (1981). Evaluating structural equation models with unobservable variables and measurement error. Journal of Marketing Research(18), 39-50.

Gersick, C. J. G. (1988). Time and transition in work teams: Toward a new model of group development. Academy of Management Journal, 31(1), 9-41. doi: 10.2307/256496

Ghazzawi, I. A. (2008). Job satisfaction among information technology professionals in the US: An empirical study. Journal of American Academy of Business, Cambridge, 13(1), 115 .

Gibson, J. L., \& Klein, S. M. (1970). Employee attitudes as a function of age and length of service: A reconceptualization. Academy of Management Journal, 13(4), 411-425. doi: $10.2307 / 254831$

Glebbeek, A. C., \& Bax, E. H. (2004). Is high employee turnover really harmful? An empirical test using company records. Academy of Management Journal, 47(2), 277-286.

Glenn, N. D., Taylor, P. A., \& Weaver, C. N. (1977). Age and job satisfaction among males and females: A multivariate, multisurvey study. Journal of Applied Psychology, 62(2), 189193. doi: 10.1037/0021-9010.62.2.189

Goldstein, D. K., \& Rockart, J. F. (1984). An examination of work-related correlates of job satisfaction in programmer/analysts. MIS Quarterly, 8(2), 103-115. doi: $10.2307 / 249347$ 
Gordon, M. E., Pryor, N. M., \& Harris, B. V. (1974). An examination of scaling bias in Herzberg's theory of job satisfaction. Organizational Behavior \& Human Performance, 11(1), 106-121.

Griffeth, R. W., Hom, P. W., \& Gaertner, S. (2000). A meta-analysis of antecedents and correlates of employee turnover: Update, moderator tests, and research implications for the next millennium. Journal of Management, 26(3), 463-488.

Guthrie, J. P. (2001). High-involvement work practices, turnover, and productivity: Evidence from New Zealand. Academy of Management Journal, 44(1), 180-190.

Guttentag, D. (2015). Airbnb: Disruptive innovation and the rise of an informal tourism accommodation sector. Current Issues in Tourism, 18(12), 1192-1217. doi: 10.1080/13683500.2013.827159

Hair, J. F., Black, W., Babin, B., \& Anderson, R. (2010). Multivariate data analysis. Upper Saddle River, NJ: Pearson.

Hair, J. F., Ringle, C. M., \& Sarstedt, M. (2013). Partial least squares structural equation modeling: Rigorous applications, better results and higher acceptance. Long Range Planning(46), 1-12. doi: 10.1016/j.lrp.2013.01.001

Hair, J. F., Sarstedt, M., Pieper, T. M., \& Ringle, C. M. (2012). The use of partial least squares structural equation modeling in strategic management research: A review of past practices and recommendations for future applications. Long Range Planning (45), 320340. doi: 10.1016/j.lrp.2012.09.008

Haire, M., Ghiselli, E. E., \& Porter, L. W. (1966). Managerial thinking: An international study. New York: Wiley.

Hardin, E. (1965). Perceived and actual changes in job satisfaction. Journal of Applied Psychology, 49(2), 363-367.

Herzberg, F. (1968). One more time: How do you motivate employees? Harvard Business Review, 46(1), 53-62.

Herzberg, F. (2003). One more time: How do you motivate employees? Harvard Business Review, 81(1), 87-96.

Herzberg, F., Mausner, B., \& Snyderman, B. (1959). The motivation to work. New York: John Wiley \& Sons, Inc.

Hewson, C., \& Laurent, D. (2008). Research design tools for internet research. In N. Fielding, R. M. Lee, \& G. Blank (Eds.), The SAGE handbook of online research methods. London: SAGE.

House, R. J., \& Wigdor, L. A. (1967). Herzberg's dual-factor theory of job satisfaction and motivation: A review of the evidence and a criticism. Personnel Psychology, 20(4), 369389.

Huselid, M.A. (1995). The Impact of Human Resource Management Pracgices on Turnover, Productivity, and Corporate Financial Performance. The Academy of Management Journal, 38(3), 635-672.

Im, J. H., \& Hartman, S. (1990). Rethinking the issue of whether IS people are different from non-IS people. MIS Quarterly, 14(1), 1-2.

Immigration New Zealand. (2015, January 14, 2015). Job markets and key industries: Information technology. Retrieved July 11, 2015, from https://www.newzealandnow.govt.nz/work-in-nz/nz-jobs-industries/informationtechnology-jobs

Jiang, J. J., \& Klein, G. (2002). A discrepancy model of Information System personnel turnover. Journal of Management Information Systems, 19(2), 249-272. 
Johnson, G. J., \& Johnson, W. R. (2000). Perceived overqualification and dimensions of job satisfaction: A longitudinal analysis. The Journal of Psychology: Interdisciplinary and Applied, 134(5), 537-555. doi: 10.1080/00223980009598235

Jones, D., Pringle, J., \& Shepherd, D. (2000). Managing diversity meets Aotearoa/New Zealand. Personnel Review, 29(3), 364-380.

Judge, T. A., Thoresen, C. J., Bono, J. E., \& Patton, G. K. (1998). The job satisfaction - job performance relationship. Paper presented at the Annual Meeting of the Academy of Management, San Diego, CA.

Jung, K., Moon, M. J., \& Hahm, S. D. (2007). Do age, gender, and sector affect job satisfaction? Results from the Korean labor and income panel data. Review of Public Personnel Administration, 27(2), 125-146.

Jyothi, B. S., \& Ravindran, P. T. (2012). Employee job satisfaction in software and ITeS units in Bangalore - An empirical study. Business Management Dynamics, 2(6), 46-55.

Kanwar, Y. P. S., Singh, A. K., \& Kodwani, A. D. (2012). A study of job satisfaction, organizational commitment and turnover intent among the IT and ITES sector employees. Vision (o9722629), 16(1), 27-35. doi: 10.1177/097226291201600103

Kifle, T., Kler, P., \& Shankar, S. (2016). Immigrant job satisfaction: The Australian experience. International Journal of Manpower, 37(1) 99-114.

Kluger, M. T., \& Bryant, J. (2008). Job satisfaction, stress and burnout in anaesthetic technicians in New Zealand. Anaesthesia \& Intensive Care, 36(2), 214-221.

Kock, N., \& Lynn, G. S. (2012). Lateral collinearity and misleading results in variance-based SEM: An illustration and recommendations. Journal of the Association for Information Systems, 13(7), 545-580.

Kristof-Brown, A. L., Zimmerman, R. D., \& Johnson, E. C. (2005). Consequences of Individuals' fit at work: A meta-analysis of person-job, person-organization, persongroup, and person-supervisor fit. Personnel Psychology, 58(2), 281-342. doi: 10.1111/j.1744-6570.2005.00672.x

Kundrátová, I. (2011). Motivating Social Workers: The Significant Factors Affecting Practical Social Work. Výzvy pre sociálne profesie v modernej spoločnosti, 94-106.

Lambert, S. J. (1991). The combined effects of job and family characteristics on the job satisfaction, job involvement, and intrinsic motivation of men and women workers. Journal of Organizational Behavior, 12(4), 341-363.

Lambert, E. G., Hogan, N. L., \& Barton, S. M. (2001). The impact of job satisfaction on turnover intent: A test of a structural measurement model using a national sample of workers. Social Science Journal, 38(2), 233-250.

Lange, T. (2012). Job satisfaction and self-employment: autonomy or personality? Small Business Economics, 38(2), 165-177. doi: 10.1007/s11187-009-9249-8

Lee, R., \& Wilbur, E. R. (1985). Age, education, job tenure, salary, job characteristics, and job satisfaction: A multivariate analysis. Human Relations, 38(8), 781-791. doi: 10.1177/001872678503800806

Lindsay, C. A., Marks, E., \& Gorlow, L. (1967). The Herzberg theory: A critique and reformulation. Journal of Applied Psychology, 51(4), 330-339.

Locke, E. A. (1977). The myths of Behavior Mod in organizations. Academy of Management Review, 2(4), 543-553. doi: 10.5465/AMR.1977.4406724

Locke, E. A., \& Latham, G. P. (2002). Building a practically Useful theory of goal setting and task motivation: A 35-year odyssey. American Psychologist, 57(9), 705-717. doi: 10.1037/0003-066X.57.9.705 
Locke, E. A., \& Latham, G. P. (2004). What should we do about motivation theory? Six recommendations for the twenty-first century. Academy of Management Review, 29(3), 388-403. doi: 10.5465/AMR.2004.13670974

Lum, L., Kervin, J., Clark, K., Reid, F., \& Sirola, W. (1998). Explaining nursing turnover intent: Job satisfaction, pay Satisfaction, or organizational commitment? Journal of Organisational Behaviour, 19(3), 305-320.

Magee, W. (2013). Anxiety, demoralization, and the gender difference in job satisfaction. Sex Roles, 69(5-6), 308-322. doi: 10.1007/s11199-013-0297-9

Mak, B. L., \& Sockel, H. (2001). A confirmatory factor analysis of IS employee motivation and retention. Information \& Management, 38(5), 265-276. doi: 10.1016/So3787206(00)00055-0

Maslow, A. H. (1943). A theory of human motivation. Psychological Review, 50(4), 370-396. doi: 10.1037/hoo54346

McClelland, D. C. (1961). The achieving society. Princeton, NJ: Van Nostrand.

McClelland, D. C. (1965). Achievement motivation can be developed. Harvard Business Review, 43(6), 6-24.

McClelland, D. C., \& Burnham, D. H. (1995). Power is the great motivator. Harvard Business Review, 73(1), 126-139.

McMurtrey, M. E., Grover, V., Teng, J. T. C., \& Lightner, N. J. (2002). Job satisfaction of Information Technology workers: The impact of career orientation and task automation in a CASE environment. Journal of Management Information Systems, 19(2), 273-302. doi: 10.1080/07421222.2002.11045719

Ministry of Business Innovation and Employment. (2015). ICT Report 2015. New Zealand Sectors Report Series. Retrieved 11 February 2016, from http://www.mbie.govt.nz/infoservices/business/business-growth-agenda/sectors-reports-series/pdf-imagelibrary/information-and-communications-technologyreport/2015\%20Information\%20and\%20Communication\%20Technology\%2oreport.p df

Mone, M. A. (1994). Relationships between self-concepts, aspirations, emotional responses, and intent to leave a downsizing organization. Human Resource Management, 33(2), 281-298.

Moore, J. E. (2000). One road to turnover: An examination of work exhaustion among technology professionals. . MIS Quarterly, 24(1), 141-168. doi: 10.2307/3250982

Moqbel, M., Nevo, S., \& Kock, N. (2013). Organization members' use of social networking sites and job performance. Information Technology \& People, 26(3), 240-264. doi: 10.1108/ITP-10-2012-0110

Myers, M. S. (1964). Who are your motivated workers? Harvard Business Review, 42(1), 7388.

Nitti, M., \& Ciavolino, E. (2014). A deflated indicators approach for estimating second-order reflective models through PLS-PM: An empirical illustration. Journal of Applied Statistics, 41(10), 2222-2239. doi: 10.1080/02664763.2014.909786

Nixon, H., \& Saphores, J.-D. M. (2007). Financing electronic waste recycling Californian households' willingness to pay advanced recycling fees. Journal of Environmental Management, 84(4), 547-559. doi: 10.1016/j.jenvman.2006.07.003

Nunnally, J. C., \& Bernstein, I. H. (1994). Psychometric theory. New York: McGraw-Hill.

NZ Human Rights Commission. (2012). NZ Census of Women's Participation. November: Wellington: NZ Human Rights Commission. 
NZ IT industry. (2015). NZ IT industry. Retrieved July 11, 2015, from https://www.linkedin.com/grp/home?gid=1522397

NZ Technology Industry Association (NZ Tech). (2016). Digital Nation New Zealand: From Tech Sector to Digital. Second edition. Retrieved on 6 February, 2017, from http://www.epageflip.net/i/722403-from-tech-sector-to-digital-nation-2nd-editionebook

Oladotun, K. J., \& Öztüren, A. (2013). Motivational factors of hospital employees: Evidence from North Cyprus. Interdisciplinary Journal of Contemporary Research in Business. 4(12), 106-123.

Oshagbemi, T., \& Hickson, C. (2003). Some aspects of overall job satisfaction: A binomial logit model. Journal of Managerial Psychology, 18(4), 357-367.

Parker, J. (2013). Defining New Zealand's Workforce and Workplace. In J. Parker (general ed.) with J. Arrowsmith, HRM and Employment Relations in New Zealand: The Big Issues (chapter 3, pp. 37-56) Auckland: CCH.

Patton, S. (2012). Where did your graduate students end up? LinkedIn knows. The Chronicle of Higher Education, 58(39).

Petter, S., Straub, D., \& Rai, A. (2007). Specifying formative constructs in Information Systems research. MIS Quarterly, 31(4), 623-656.

Porter, L. W., \& Lawler, E. E. (1968). Managerial attitudes and performance. Homewood, IL: Irwin-Dorsey.

Rajagopal, N., \& Abraham, S. (2009). Prominence of higher order needs: An Indian IT sector experience. Vilakshan: The XIMB Journal of Management, 6(2), 15-28.

Ramachndran, S., \& Rao, S. V. (2006). An effort towards identifying occupational culture among information systems professionals. Paper presented at the ACM SIGMIS CPR conference on computer personnel research, Claremont, CA.

Rigdon, E. E. (2012). Rethinking partial least squares path modeling: In praise of simple methods. Long Range Planning (45), 3341-3358. doi: 10.10.16/j.lrp.2012.09.010

Ringle, C. M., Sarstedt, M., \& Straub, D. W. (2012). Editor's comments: A critical look at the use of PLS-SEM. MIS Quarterly, 36(1), iii-xiv.

Robinson, S. D., Sinar, E., \& Winter, J. (2014). Social media as a tool for research: A turnover application using LinkedIn. TIP: The Industrial-Organizational Psychologist, 52(1), 133-141.

Roethlisberger, F., \& Dickson, W. (1939). Management and the worker. Cambridge, MA: Harvard University Press.

Ryan, R. (2012). Contextualising HRM in NZ. In R. Ryan and J. Bryson (eds), Critical Perspectives on HRM: A Primer (chapter 3). Auckland: Pearson Educational.

Saari, L. M., \& Judge, T. A. (2004). Employee attitudes and job satisfaction. Human Resource Management, 43(4), 395-407. doi: 10.1002/hrm.20032

Saleh, S. D. (1964). Study of attitude change in the preretirement period. Journal of Applied Psychology, 48, 310-312. doi: 10.1037/ho042932

Schambach, T., \& Blanton, J. E. (2002). The professional development challenge for IT professionals. Communications of the ACM, 45(4), 83-87. doi: 10.1145/505248.505250

Schor, J. (2008). The overworked American: The unexpected decline of leisure. New York: Basic Books.

Schuster, J. R., Clark, B., \& Rogers, M. (1971). Testing portions of the Porter and Lawler model regarding the motivational role of pay. Journal of Applied Psychology, 55(3), 187-195. 
Shiu, E., Hassan, L. M., \& Parry, S. (2015). The model effects of national age stereotyping on the relationship between job satsifaction and its determinants: A study of older workers across 26 countries. British Journal of Management, 26(1), 255-272. doi: 10.1111/14678551.12091

Shuck, B., Twyford, D., Reio, T. G., Jr., \& Shuck, A. (2014). Human resource development practices and employee engagement: Examining the connection with employee turnover intentions. Human Resource Development Quarterly, 25(2), 239-270.

Singh, P., \& Loncar, N. (2010). Pay satisfaction, job satisfaction and turnover intent. Relations Industrielles / Industrial Relations, 65(3), 470-490.

Smerek, R., \& Peterson, M. (2007). Examining Herzberg's theory: Improving job satisfaction among non-academic employees at a university. Research in Higher Education, 48(2), 229-250. doi: 10.1007/s11162-006-9042-3

Smith, D. B., \& Shields, J. (2013). Factors related to social service workers' job satisfaction: Revisiting Herzberg's motivation to work. Administration in Social Work, 37(2), 189198. doi: 10.1080/03643107.2012.673217

Smith, D. C., \& Speight, H. L. (2006). Antecedents of turnover intention and actual turnover among information systems personnel in South Africa. Paper presented at the 2006 ACM SIGMIS CPR conference on computer personnel research, Germany.

Souder, W. E., Buisson, D., \& Garrett, T. (1997). Success through customer-driven new product development: a comparison of US and New Zealand small entrepreneurial high technology firms. Journal of Product Innovation Management, 14(6), 459-472.

Statistics NZ. (2013a). New Zealand IT demographics by sex. (JOB-05804).

Statistics NZ. (2013b). Occupation (ANZSCO) (ICT groups) and status in employment by age groups and sex. (JOB-07133).

Stoikov, V. (1971). The effect of changes in quits and hires on the length-of-service composition of employed workers. British Journal of Industrial Relations, 9(2), 225-233.

Straub, D. W., Boudreau, M.-C., \& Gefen, D. (2004). Validation guidelines for IS positivist research. Communications of the AIS(13), 380-427.

Stuart, F. I., Verville, J., \& Taskin, N. (2012). Trust in buyer-supplier relationships. Journal of Enterprise Information Management, 25(4), 392-412.

Sykes, A. J. M. (1965). Economic interest and the Hawthorne Researches. Human Relations, 18(3), 253-263.

Tang, T. L.-P., \& Gilbert, P. R. (1995). Attitudes toward money as related to intrinsic and extrinsic job satisfaction, stress and work-related attitudes. Personality and Individual Differences, 19(3), 327-332. doi: 10.1016/0191-8869(95)oo057-D

Tanner, F. R. (2003). Managing technologically driven organizations, The human side of innovation and change. Paper presented at the Engineering Management Conference.

Taylor, G. S., \& Vest, M. J. (1992). Pay comparisons and pay satisfaction among public sector employees. Public Personnel Management, 21(4), 445-454.

Tietjen, M. A., \& Myers, R. M. (1998). Motivation and job satisfaction. Management Decision, 36(4), 226-231. doi: 10.1108/00251749810211027

Toulson, P., \& Foster, B. (2013). the relevance of historical context to HRM and employment relations. In J. Parker (general ed.) with J. Arrowsmith, HRM and Employment Relations in New Zealand: The Big Issues (chapter 2, pp. 15-35) Auckland: CCH.

Tryon, W. W. (1981). A methodological critique of Bandura's self-efficacy theory of behavior change. Journal of Behavior Therapy and Experimental Psychiatry, 12(2), 113-114. doi: 10.1016/0005-7916(81)90003-3 
Tzeng, H.-M. (2002). The influence of nurses' working motivation and job satisfaction on intention to quit: an empirical investigation in Taiwan. International Journal of Nursing Studies, 39, 867-878. doi: 10.1016/So020-7489(02)00027-5

Urbach, N., \& Ahlemann, F. (2010). Structural equation modeling in Information Systems research using Partial Least Squares. Journal of Information Technology Theory and Application, 11(2), 5-40.

Verquer, M. L., Beehr, T. A., \& Wagner, S. H. (2003). A meta-analysis of relations between person-prganization fit and work attitudes. Journal of Vocational Behavior, 63(3), 473489.

Volkwein, J. F., \& Zhou, Y. (2003). Testing a model of administrative job satisfaction. Research in Higher Education, 44(2), 149-171.

Vroom, V. H. (1964). Work and motivation. New York: Wiley.

Vroom, V. H. (1966). Some observations regarding Herzberg's two-factor theory. Paper presented at the American Psychological Association Convention, New York.

Wagner, J. A., Rubin, P. A., \& Callahan, T. J. (1988). Incentive payment and nonmanagerial productivity: An interrupted time series analysis of magnitude and trend. Organizational Behavior and Human Decision Processes, 42(1), 47-74. doi: 10.1016/0749-5978(88)90019-2

Wahba, M. A., \& Bridwell, L. G. (1976). Maslow reconsidered: A review of research on the need hierarchy theory. Organizational Behavior \& Human Performance, 15(2), 212-240.

Wallace, J., \& Gaylor, K. P. (2012). A study of the dysfunctional and functional aspects of voluntary employee turnover. SAM Advanced Management Journal (o7497075), 77(3), 27-36.

Wickström, G., \& Bendix, T. (2000). The" Hawthorne effect"- what did the original Hawthorne studies actually show? Scandinavian journal of work, environment \& health, 363-367.

Williamson, D. A. (1996). Job satisfaction in social services. New York: Garland.

Wilson, P. M., Rodgers, W. M., Carpenter, P. J., Hall, C., Hardy, J., \& Fraser, S. N. (2004). The relationship between commitment and exercise behavior. Psychology of Sport and Exercise(5), 405-421. doi: 10.1016/S1469-0292(03)00035-9

Wynekoop, J. L., \& Walz, D. B. (1998). Revisiting the perennial question: Are IS people different? The Database for Advances in Information Systems, 29(2), 67-72.

Copyright: (C) 2017 Ahmed, Taskin, Pauleen \& Parker. This is an open-access article distributed under the terms of the Creative Commons Attribution-NonCommercial 3.0 Australia License, which permits non-commercial use, distribution, and reproduction in any medium, provided the original author and AJIS are credited. 
Australasian Journal of Information Systems 2017, Vol 21, Research Article
Ahmed, Taskin, Pauleen \& Parker

Motivating Information Technology Professionals

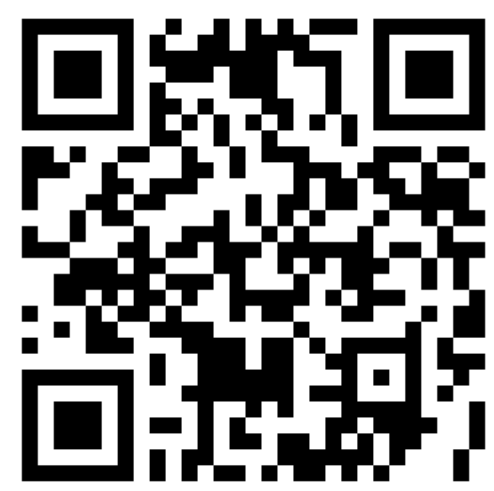




\section{Appendices}

\begin{tabular}{|c|c|c|c|c|c|c|c|c|c|c|c|c|c|c|c|}
\hline & REC & WRK & ADV & GTH & RSP & GFO & MIS & SMG & SPV & CWR & SAL & BEN & VAL & SAT & TRN \\
\hline REC_1 & .794 & .406 & .157 & .212 & .013 & .016 & .054 & .232 & .033 & .036 & .054 & .113 & .080 & .340 & .077 \\
\hline REC_2 & .821 & .411 & .251 & .098 & .206 & .068 & .071 & .177 & .035 & .010 & .050 & .099 & .121 & .451 & .072 \\
\hline REC_3 & .733 & .085 & .011 & .037 & .334 & .150 & .236 & .039 & .096 & .127 & .030 & .093 & .109 & .090 & .045 \\
\hline REC_4 & .819 & .347 & .144 & .206 & .112 & .045 & .174 & .138 & .003 & .109 & .108 & .007 & .145 & .372 & .155 \\
\hline REC_5 & .710 & .441 & .289 & .076 & .038 & .007 & .099 & .264 & .018 & .058 & .025 & .137 & .049 & .379 & .037 \\
\hline WRK_1 & .139 & .940 & .146 & .084 & .062 & .126 & .049 & .068 & .028 & .005 & .002 & .062 & .093 & .019 & .070 \\
\hline WRK_2 & .005 & .963 & .063 & .086 & .141 & .021 & .064 & .009 & .042 & .007 & .022 & .019 & .041 & .074 & .053 \\
\hline WRK_3 & .028 & .961 & .074 & .047 & .026 & .004 & .053 & .028 & .031 & .045 & .039 & .045 & .010 & .101 & .043 \\
\hline WRK_4 & .113 & .872 & .146 & .133 & .250 & .110 & .077 & .095 & .051 & .036 & .017 & .039 & .156 & .214 & .031 \\
\hline ADV_1 & .085 & .214 & .840 & .267 & .057 & .109 & .192 & .168 & .121 & .038 & .014 & .150 & .159 & .278 & .006 \\
\hline ADV_2 & .064 & .096 & .851 & .018 & .212 & .163 & .067 & .001 & .145 & .129 & .027 & . 047 & .039 & .015 & .153 \\
\hline ADV_3 & .113 & .016 & .819 & .033 & .126 & .137 & .277 & .144 & .119 & .137 & .020 & .085 & .043 & .135 & .111 \\
\hline ADV_4 & .108 & .120 & .708 & .258 & .467 & .167 & .012 & .031 & .168 & .042 & .026 & .220 & .192 & .469 & .305 \\
\hline GTH_1 & .038 & .068 & .040 & .884 & .065 & .110 & .042 & .108 & .051 & .015 & .023 & .025 & .071 & .104 & .017 \\
\hline GTH_2 & .010 & .052 & .033 & .883 & .022 & .176 & .091 & .116 & .038 & .008 & .017 & .011 & .027 & .128 & .049 \\
\hline GTH_3 & .014 & .044 & .068 & .868 & .115 & .007 & .298 & .065 & .090 & .023 & .133 & . 085 & .047 & .020 & .010 \\
\hline GTH_4 & .056 & .027 & .003 & .879 & .131 & .178 & .222 & .080 & .219 & .024 & .143 & .010 & .062 & .058 & .033 \\
\hline GTH_5 & .046 & .115 & .153 & .793 & .078 & .130 & .228 & .089 & .044 & .059 & .032 & .063 & .092 & .171 & .026 \\
\hline RSP_1 & .101 & .048 & .101 & .018 & .891 & .084 & .019 & .125 & .060 & .026 & .070 & . .044 & .044 & .064 & .059 \\
\hline RSP_2 & .099 & .064 & .077 & .039 & .907 & .001 & .138 & .041 & .010 & .043 & .048 & .102 & .012 & .191 & .047 \\
\hline RSP_3 & .010 & .064 & .046 & .016 & .897 & .035 & .205 & .041 & .055 & .058 & .060 & .007 & .070 & .075 & .114 \\
\hline RSP_4 & .087 & .024 & .086 & .013 & .811 & .039 & .215 & .014 & .062 & .004 & .039 & .083 & .131 & .304 & .106 \\
\hline RSP_5 & .074 & .064 & .109 & .058 & .829 & .090 & .182 & .058 & .045 & .040 & .024 & .010 & .018 & .061 & .008 \\
\hline GFO_1 & .196 & .155 & .289 & .055 & .007 & .881 & .029 & .065 & .037 & .100 & .008 & .108 & .038 & .266 & .093 \\
\hline GFO_2 & .016 & .113 & .225 & .160 & .193 & .876 & .071 & .095 & .000 & .006 & .072 & .077 & .163 & .274 & .104 \\
\hline GFO_3 & .050 & .091 & .111 & .012 & .007 & .933 & .117 & .042 & .038 & .040 & .016 & .061 & .025 & .123 & .030 \\
\hline GFO_4 & .037 & .004 & .109 & .058 & .006 & .955 & .019 & .069 & .079 & .030 & .051 & .013 & .088 & .026 & .018 \\
\hline GFO_5 & .124 & .183 & .287 & .143 & .192 & .849 & .047 & .042 & .169 & .020 & .043 & .110 & .081 & .453 & .191 \\
\hline MIS_1 & .026 & .120 & .044 & .017 & .097 & .047 & .886 & .201 & .197 & .151 & .099 & .014 & .103 & .303 & .218 \\
\hline MIS_2 & .020 & .096 & .017 & .010 & .158 & .027 & .910 & .181 & .138 & .040 & .083 & .012 & .046 & .196 & .115 \\
\hline MIS_3 & .052 & .080 & .013 & .023 & .108 & .024 & .918 & .180 & .081 & .021 & .062 & .038 & .042 & .151 & .070 \\
\hline MIS_4 & .110 & .063 & .063 & .105 & .380 & .155 & .810 & .108 & .270 & .022 & .186 & .014 & .008 & .197 & .120 \\
\hline MIS_5 & .001 & .260 & .103 & .094 & .019 & .056 & .721 & .476 & .023 & .155 & .010 & .019 & .086 & .361 & .255 \\
\hline MIS_6 & .001 & .037 & .104 & .018 & .044 & .004 & .795 & .317 & .175 & .076 & .079 & .073 & .034 & .208 & .102 \\
\hline SMG_1 & .018 & .023 & .025 & .013 & .035 & .055 & .022 & .964 & .020 & .018 & .002 & .039 & .080 & .016 & .056 \\
\hline SMG_2 & .064 & .027 & .080 & .025 & .001 & .017 & .069 & .967 & .081 & .030 & .015 & .046 & .055 & .093 & .055 \\
\hline SMG_3 & .047 & .051 & .107 & .039 & .036 & .038 & .048 & .950 & .102 & .048 & .018 & .007 & .026 & .079 & .001 \\
\hline SPV_1 & .007 & .050 & .075 & .058 & .054 & .083 & .107 & .124 & .951 & .035 & .015 & .023 & .109 & .025 & .006 \\
\hline SPV_2 & .055 & .022 & .019 & .161 & .137 & .068 & .139 & .099 & .922 & .083 & .010 & .003 & .026 & .131 & .101 \\
\hline SPV_3 & .086 & .021 & .073 & .078 & .065 & .098 & .086 & .162 & .940 & .046 & .021 & .030 & .073 & .030 & .059 \\
\hline SPV_4 & .055 & .001 & .050 & .039 & .091 & .119 & .048 & .035 & .964 & .009 & .003 & .005 & .039 & .013 & .011 \\
\hline SPV_5 & .044 & .025 & .024 & .017 & .053 & .017 & .060 & .030 & .964 & .073 & .039 & .020 & .031 & .063 & .028 \\
\hline SPV_6 & .050 & .019 & .121 & .054 & .071 & .059 & .004 & .102 & .947 & .049 & .016 & .061 & .065 & .059 & .004 \\
\hline SPV_7 & .007 & .066 & .091 & .022 & .141 & .100 & .042 & .029 & .913 & .021 & .026 & .024 & .040 & .094 & .107 \\
\hline
\end{tabular}




\begin{tabular}{|c|c|c|c|c|c|c|c|c|c|c|c|c|c|c|c|}
\hline & REC & WRK & $\mathrm{ADV}$ & GTH & RSP & GFO & MIS & SMG & SPV & CWR & SAL & BEN & VAL & SAT & TRN \\
\hline SPV_8 & .050 & .023 & .017 & .153 & .029 & .047 & .006 & .099 & .911 & .119 & .054 & .110 & .083 & .051 & .066 \\
\hline SPV_9 & .096 & .102 & .116 & .073 & .045 & .064 & .088 & .038 & .938 & .036 & .080 & .031 & .004 & .028 & .019 \\
\hline SPV_11 & .041 & .055 & .023 & .143 & .098 & .072 & .048 & .007 & .937 & .056 & .042 & .025 & .020 & .038 & .049 \\
\hline SPV_12 & .220 & .069 & .083 & .071 & .093 & .045 & .045 & .013 & .868 & .134 & .013 & .113 & .022 & .064 & .156 \\
\hline SPV_13 & .039 & .024 & .101 & .057 & .112 & .122 & .132 & .067 & .919 & .071 & .004 & .051 & .027 & .022 & .037 \\
\hline SPV_14 & .006 & .007 & .054 & .113 & .168 & .100 & .179 & .182 & .910 & .014 & .020 & .005 & .021 & .051 & .020 \\
\hline SPV_15 & .055 & .112 & .114 & .183 & .032 & .219 & .110 & .137 & .842 & .155 & .068 & .062 & .069 & .029 & .025 \\
\hline CWR_1 & .032 & .227 & .038 & .057 & .070 & .026 & .071 & .116 & .124 & .886 & .070 & .026 & .021 & .056 & .050 \\
\hline CWR_2 & .003 & .009 & .103 & .146 & .147 & .234 & .043 & .157 & .092 & .863 & .074 & .049 & .056 & .073 & .038 \\
\hline CWR_3 & .076 & .020 & .093 & .178 & .019 & .037 & .035 & .034 & .070 & .870 & .145 & .075 & .069 & .087 & .011 \\
\hline CWR_4 & .047 & .109 & .131 & .156 & .045 & .029 & .163 & .057 & .035 & .907 & .059 & .063 & .006 & .058 & .029 \\
\hline CWR_5 & .017 & .102 & .069 & .140 & .042 & .203 & .085 & .106 & .146 & .825 & .004 & .003 & .111 & .030 & .066 \\
\hline CWR_6 & .031 & .178 & .258 & .177 & .098 & .050 & .036 & .147 & .174 & .687 & .073 & .093 & .025 & .011 & .088 \\
\hline CWR_7 & .179 & .114 & .033 & .021 & .009 & .070 & .231 & .227 & .128 & .746 & .339 & .169 & .032 & .111 & .041 \\
\hline SAL_1 & .048 & .090 & .101 & .113 & .051 & .005 & .007 & .045 & .043 & .062 & .947 & .088 & .003 & .109 & .041 \\
\hline SAL_2 & .103 & .090 & .018 & .033 & .049 & .008 & .070 & .081 & .040 & .034 & .950 & .021 & .062 & .123 & .069 \\
\hline SAL_3 & .180 & .215 & .141 & .094 & .119 & .004 & .092 & .150 & .003 & .114 & .796 & .079 & .071 & .277 & .131 \\
\hline BEN_1 & .019 & .050 & .032 & .034 & .023 & .021 & .045 & .009 & .005 & .064 & .153 & .924 & .012 & .112 & .034 \\
\hline BEN_2 & .173 & .033 & .223 & .086 & .105 & .006 & .132 & .073 & .026 & .108 & .062 & .886 & .024 & .096 & .177 \\
\hline BEN_3 & .057 & .037 & .259 & .039 & .117 & .029 & .199 & .076 & .182 & .017 & .216 & .708 & .107 & .065 & .012 \\
\hline BEN_4 & .152 & .058 & .051 & .085 & .037 & .052 & .075 & .023 & .172 & .194 & .051 & .855 & .100 & .076 & .137 \\
\hline VAL_1 & .094 & .093 & .130 & .154 & .015 & .077 & .165 & .093 & .074 & .001 & .090 & .069 & .895 & .102 & .038 \\
\hline VAL_2 & .024 & .055 & .081 & .111 & .057 & .062 & .035 & .051 & .004 & .028 & .017 & .109 & .936 & .155 & .040 \\
\hline VAL_3 & .067 & .034 & .044 & .037 & .043 & .012 & .127 & .144 & .069 & .027 & .107 & .043 & .910 & .059 & .004 \\
\hline SAT_1 & .022 & .158 & .110 & .022 & .072 & .006 & .007 & .050 & .043 & .041 & .007 & .041 & .112 & .945 & .039 \\
\hline SAT_2 & .071 & .029 & .055 & .023 & .072 & .039 & .051 & .002 & .033 & .011 & .077 & .028 & .153 & .951 & .037 \\
\hline SAT_3 & .096 & .192 & .056 & .002 & .148 & .034 & .046 & .049 & .011 & .031 & .073 & .071 & .043 & .924 & .078 \\
\hline TRN_1 & .005 & .190 & .005 & .003 & .049 & .042 & .009 & .050 & .113 & .047 & .016 & .087 & .008 & .078 & .895 \\
\hline TRN_2 & .078 & .044 & .120 & .024 & .261 & .167 & .157 & .070 & .128 & .034 & .012 & .061 & .087 & .147 & .853 \\
\hline TRN_3 & .095 & .316 & .162 & .036 & .271 & .273 & .192 & .023 & .013 & .108 & .007 & .039 & .102 & .296 & .659 \\
\hline
\end{tabular}

\begin{tabular}{|lllll|}
\hline Legend: & REC & Recognition & WRK & Work itself \\
& ADV & Opportunities for advancement & GTH & Professional growth opportunities \\
RSP & Responsibility & GFO & Good feelings for organization \\
MIS & Clarity of mission & SMG & Effective senior management \\
SPV & Effective supervisor & CWR & Good relations with co-workers \\
SAL & Satisfaction with salary & BEN & Satisfaction with benefits \\
VAL & Presence of core values & SAT & Job satisfaction \\
TRN & Turnover intent & & \\
\hline
\end{tabular}

Table A1: CFA first order factor loadings 


\begin{tabular}{|c|c|c|c|c|}
\hline \multirow[b]{2}{*}{ Factor } & \multirow[b]{2}{*}{ Indicator } & \multirow[b]{2}{*}{ Sig. } & \multicolumn{2}{|c|}{ VIFs } \\
\hline & & & Indicator & Construct \\
\hline \multirow{7}{*}{ Intrinsic motivation } & Recognition & * & 1.670 & \multirow{7}{*}{$4 \cdot 719$} \\
\hline & Work itself & * & 1.875 & \\
\hline & Opportunities for advancement & * & 1.962 & \\
\hline & Professional growth opportunities & * & 1.800 & \\
\hline & Responsibility & $*$ & 2.670 & \\
\hline & Good feelings about organization & * & 2.145 & \\
\hline & Clarity of mission & * & 2.610 & \\
\hline \multirow{6}{*}{ Extrinsic motivation } & Effective senior management & $* *$ & 2.070 & \multirow{6}{*}{3.470} \\
\hline & Effective supervisor & $*$ & 1.560 & \\
\hline & Good relations with co-workers & * & 1.477 & \\
\hline & Satisfaction with salary & * & 1.800 & \\
\hline & Satisfaction with benefits & * & 1.611 & \\
\hline & Presence of core values & $*$ & 1.956 & \\
\hline \multirow{9}{*}{ Control variables } & Gender & $* *$ & 1.319 & \\
\hline & Age & $* *$ & 2.972 & \\
\hline & Qualifications & $* *$ & 1.285 & \\
\hline & Born in & ** & 1.275 & \\
\hline & Tenure (years) & $* *$ & 1.287 & \\
\hline & Experience (years) & $* *$ & 3.403 & \\
\hline & Salary & $* *$ & 2.123 & \\
\hline & Bonus & $* *$ & 2.197 & \\
\hline & Professional membership & $* *$ & 1.336 & \\
\hline
\end{tabular}

Note: ${ }^{*}=$ significant at $p<.01,{ }^{* *}=$ significant at $p<.001$

Table A2: Indicator validity

\begin{tabular}{llllll}
\hline \multirow{2}{*}{ Control variable } & \multicolumn{2}{c}{ Welch $\boldsymbol{F}$} & & \multicolumn{2}{c}{ Brown-Forsythe } \\
\cline { 2 - 3 } \cline { 5 - 6 } Gender & Statistic & Significance & & Statistic & Significance \\
Age & 2.500 & .120 & & 2.500 & .120 \\
Qualification & 3.123 & .034 & & 2.903 & .033 \\
Income & 1.595 & .226 & & 1.603 & .218 \\
\hline
\end{tabular}

Table A3: Non-response bias test 